NUCLEAR REACTOR TECHNOLOGY AND SCIENTIFIC COMPUTATIONS

$\begin{array}{ll}\text { KEY WORDS: } & \text { IN-TANK PRECIPITATION } \\ & \text { HUMAN RELIABILITY ANALYSIS } \\ & \text { HUMAN FACTORS } \\ & \text { PROBABILISTIC RISK ASSESSMENT } \\ \text { RETENTION: } & \text { LIFETIME }\end{array}$

HUMAN RELIABILITY ANALYSIS FOR IN-TANK PRECIPITATION ALIGNMENT AND STARTUP OF EMERGENCY PURGE VENTILATION EQUIPMENT (U)

By

LINDA M. OLSEN $4-5228$

REVISION 1 ISSUED: AUGUST 1993

Authorized Derivative Classifier

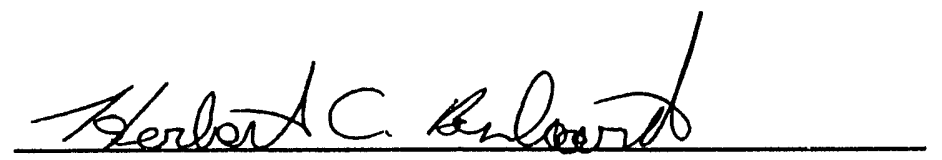

H. C. Benhardt

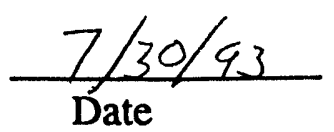

Westinghouse Savannah River Company

Savannah River Site Aiken, SC 29808 
DOCUMENT:

TITLE:
WSRC-TR-93-301, REVISION 1

HUMAN RELIABILITY ANALYSIS FOR IN-TANK

PRECIPITATION ALIGNMENT AND STARTUP OF

EMERGENCY PURGE VENTILATION EQUIPMENT (U)

APPROVALS
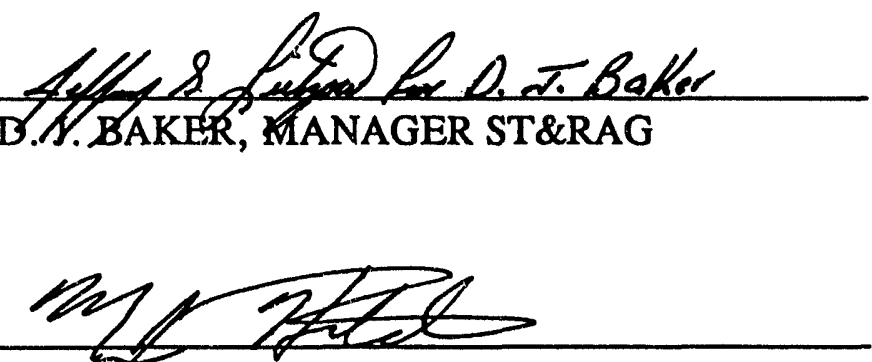

M.J TITCHLER, MANAGER STS

Beth Vaie

BETH VAIL, TECHNICAL REVIEWER

OD Menna

J. D. MEINNA, CUSTOMER
DATE: $764 / 93$

DATE: $7 / 2 / 49$

DATE: $1 / 20 / 93$

DATE: $8 / 3 / 43$ 


\section{DISCLAIMER}

This report was prepared as an account of wort spoasored by an ageacy of the United States Government. Neither the United States Government nor any agency thereof, nor any of their cmployees. makes any warranty, express or implied, or assumes any legal liability or responsibility for the accuracy, completeness, or usefulness of any information. apparatus, product, or process disclosed, or represeats that its use would not infriage privately owned rights. Reference berein to any specific commercial product, process, or service by trade name. trademart, manufacturer, or otherwise does not necessarily constitute or imply its endorsement, recommendation, or favorias by the United States Government or any agency thereof. The views, and opinions of authors expressed berein do not necessarily state or reflect those of the United States Governmeat or any ageacy ihereof.

This report has been reproduced directly from the best available copy.

Available to DOE and DOE contractors from the Office of Scientific and Technical information, P. O. Box 62, OAk Ridge. TN 37831: prices available from (615) $576-8401$.

Available to the public from the National Technical Information Service. U. S. Departmeat of Commerce, 5285 Port Royal Rd., Spriagrield. VA 22161 
REPORT REVISION LOG

\begin{tabular}{|c|c|c|}
\hline REVISION & $\begin{array}{c}\text { AFFECTED } \\
\text { PAGES }\end{array}$ & DESCRIPTION OF REVISION \\
\hline 0 & ALL & ORIGNAL ISSUE \\
\hline 1 & 1 & $\begin{array}{l}\text { PARAGRAPH 3, DEFINED 4.2E-6 AS MEDIAN } \\
\text { VALUE ON LOGNORMAL SCALE }\end{array}$ \\
\hline 1 & 2 & $\begin{array}{l}\text { PARAGRAPH 3, ADDED EXAMPLES OF OTHER } \\
\text { EVENT INITIATORS }\end{array}$ \\
\hline 1 & $3-5$ & $\begin{array}{l}\text { ASSUMPTIONS REVISED PER WASTE } \\
\text { MANAGEMENT OPERATIONS' PROCEDURES }\end{array}$ \\
\hline 1 & 6 & PARAGRAPH 3, LAST SENTENCE DELETED \\
\hline 1 & 7 & $\begin{array}{l}\text { PARAGRAPH 4, SENTENCE 3, REDEFINED } \\
\text { SHORT METHOD }\end{array}$ \\
\hline 1 & 8 & $\begin{array}{l}\text { PARAGRAPH 1, OSR REQUIREMENT } \\
\text { CHANGED TO } 14 \text { HOURS }\end{array}$ \\
\hline 1 & 8 & $\begin{array}{l}\text { PARAGRAPH 5, "PURGE FLOW METER" } \\
\text { CHANGED TO "FLOW INDICATOR" }\end{array}$ \\
\hline 1 & 8 & PARAGRAPH 6, "LEL" CHANGED TO "LFL" \\
\hline 1 & $9-12$ & $\begin{array}{l}\text { STEPS "A" THROUGH "J" - REFERENCES TO } \\
\text { ASSUMPTION NUMBERS CHANGED TO } \\
\text { REFLECT RENUMBERING OF THE } \\
\text { ASSUMPTIONS }\end{array}$ \\
\hline 1 & 9 & $\begin{array}{l}\text { STEP "A" - OSR REQUIREMENT CHANGED TO } \\
14 \text { HOURS }\end{array}$ \\
\hline 1 & 10 & $\begin{array}{l}\text { STEP "C" - NOTE ADDED TO EXPLAIN } \\
\text { ERRORS NOT MODELED }\end{array}$ \\
\hline
\end{tabular}




\begin{tabular}{|c|c|c|}
\hline REVISION & $\begin{array}{l}\text { AFFECTED } \\
\text { PAGES }\end{array}$ & DESCRIPTION OF REVISION \\
\hline 1 & $10-11$ & $\begin{array}{l}\text { STEP "D", SENTENCE } 5 \text { - "DOWN COMER" } \\
\text { DELETED. NOTE ADDED TO EXPLAIN } \\
\text { ERRORS NOT MODELED }\end{array}$ \\
\hline 1 & 11 & $\begin{array}{l}\text { STEP "H" - "PURGE FLOW METER" CHANGED } \\
\text { TO "FLOW INDICATOR" }\end{array}$ \\
\hline 1 & 12 & STEP "J" - "LEL" CHANGED TO "LFL" \\
\hline 1 & 13 & $\begin{array}{l}\text { "CONCLUSIONS", ADDED SENTENCE "THIS } \\
\text { HEP IS A MEDIAN VALUE ON THE } \\
\text { LOGNORMAL SCALE." }\end{array}$ \\
\hline 1 & 15 & ADDED REFERENCES $6,10 \& 11$ \\
\hline 1 & 17 & $\begin{array}{l}\text { ADDED "REVISED HRA TIME ESTIMATE" } \\
\text { COLUMN TO TABLE }\end{array}$ \\
\hline 1 & 37 & $\begin{array}{l}\text { TIMELINE MODIFIED TO REFLECT CHANGE } \\
\text { IN OSR REQUIREMENT FROM } 12 \text { HOURS TO } 14 \\
\text { HOURS }\end{array}$ \\
\hline
\end{tabular}


TABLE OF CONTENTS

REPORT REVISION LOG
EXECUTIVE SUMMARY
INTRODUCTION

DISCUSSION _ _ 2

Input Data

Assumptions__ 2

ANALYSIS METHODS AND CALCULATIONS__ 5

RESULTS

Summary of Operator Actions in Event Tree 7

HRA Event Tree Branch Definitions

Calculation of Failure Probabilities

CONCLUSIONS _ 13

Other Recommendations____ 13

REFERENCES______ 15

APPENDIX A: TIME ESTIMATES__ 17

APPENDIX B: TASK ANALYSES

APPENDIX C: TIMELINE___ 37

\section{LIST OF FIGURES}

Figure 1. HRA Event Tree for Align and Start Emergency Purge Ventilation Equipment on In-Tank Precipitation Tank 48 or 49 After a Seismic Event_9 


\section{EXECUTIVE SUMMMARY}

This report documents the methodology used for calculating the human error probability for establishing air based ventilation using emergency purge ventilation equipment on In-Tank Precipitation (ITP) processing tanks 48 and 49 after a failure of the nitrogen purge system following a seismic event. The analyses were performed according to THERP (Technique for Human Error Rate Prediction) as described in NUREG/CR-1278-F, "Handbook of Human Reliability Analysis with Emphasis on Nuclear Power Plant Applications". The calculated human error probabilities are provided as input to the Fault Tree Analysis for the ITP Nitrogen Purge System.

The analysis assumes a seismic event initiator leading to establishing air based ventilation on the ITP processing tanks 48 and 49 . At the time of this analysis only the tanks and the emergency purge ventilation equipment are seismically qualified. Consequently, onsite and offsite power is assumed to be unavailable and all operator control actions are to be performed locally on the tank top. A task analysis was performed for this task and is documented in Appendix B. The task analysis was done for the Off Normal Procedure (ONP), "Loss of Ventilation" and the Standard Operating Procedure (SOP), "Tank 48 System". Only those sections directly applicable to the alignment and startup of the emergency purge ventilation equipment on tank 48 were analyzed. Due to the current startup mode of ITP operations several assumptions had to be made in order to perform this analysis. Assumptions regarding procedures, staffing, equipment locations, equipment tagging, equipment availability, and training were made and are documented in this report.

The human error probability for establishing air based ventilation using the emergency purge ventilation equipment on In-Tank Precipitation processing tanks 48 and 49 after a failure of the nitrogen purge system following a seismic event is 4.2E-6 (median value on the lognormal scale). It is important to note that this result is predicated on the implementation of all of the assumptions listed in the "Assumptions" section of this report. This analysis was not based on the current conditions in ITP. The analysis is to be used as a tool to aid ITP operations personnel in achieving the training, procedural, and operational goals outlined in this document. If all of the assumptions are implemented as specified before startup, then th $=$ HEP of $4.2 \mathrm{E}-6$ is valid. If any of the assumptions are not implemented, then a reanalysis of the HEP must be performed. 


\title{
HUMAN RELIABILITY ANALYSIS FOR IN-TANK PRECIPITATION ALIGNMENT AND STARTUP OF EMERGENCY PURGE VENTILATION EQUIPMENT (U)
}

\author{
By Linda M. Olsen
}

\author{
Westinghouse Savannah River Company \\ Savannah River Technology Center \\ Aiken, SC 29808
}

\section{INTRODUCTION}

This report documents the methodology used for calculating the human error probability for establishing air based ventilation using emergency purge ventilation equipment on In-Tank Precipitation (ITP) processing tanks 48 and 49 after a failure of the nitrogen purge system following a seismic event. The analyses were performed according to THERP (Technique for Human Error Rate Prediction) as described in NUREG/CR-1278-F, "Handbook of Human Reliability Analysis with Emphasis on Nuclear Power Plant Applications". The calculated human error probabilities are provided as input to the Fault Tree Analysis for the ITP Nitrogen Purge System.

\section{DISCUSSION}

\section{Input Data}

Operator error rates were taken from data tables (Tables 20-1 through 20-27 and the Nominal Diagnosis Model) in NUREG/CR-1278-F, "Handbook of Human Reliability Analysis with Emphasis on Nuclear Power Plant Applications," with some modifications for facility-specific circumstances.

\section{Assumptions}

These assumptions are based on an analysis of tank 48 . However, since tank 49 is a mirror image of tank 48 , the assumptions used on tank 48 are applicable to tank 49 also. This analysis assumes a seismic event initiator and is bounding for all other event initiators (e.g., high winds, loss of power, etc.) resulting in establishing air based ventilation on tanks 48 or 49 using the emergency purge ventilation equipment. 
The following items that have been assumed in this analysis must be implemented in order to validate the HRA calculation:

1) Operations personnel have 3 days following the seismic event to establish air based ventilation using the emergency purge ventilation equipment before exceeding the LFL (Lower Flammability Limit).

Note: The amount of time available to recover from the seismic event is a critical factor in the calculation of the Human Error Probability (HEP). Since 3 days are available to establish air based ventilation, the HEP is not adjusted to factor in stress effects. Stress levels are assumed to subside to optimal levels at 24 to 48 hours after the seismic event. The effect on human performance of the passage of time following an initiating event is illustrated in figure 17-2, page 17-15 of NUREG/CR-1278-F.

The amount of time available to recover is also a key factor for this analysis to be bounding for severe earthquakes. Although this calculation assumes 3 days to be available for recovery, only negligible credit is taken for 2 shifts during a 24 hour period to recover from any errors in hookup of the emergency purge ventilation equipment. (See step "I" page 12 of this report.) Since negligible credit is taken for this recovery, one could assume that following a severe earthquake, 24 to 48 hours is available to recover from the immediate effects of the event on personnel health and safety. Consequently, even if no diagnosis of the need to establish air based ventilation occurs until 24 to 48 hours after an earthquake, the calculated HEP would remain unaffected.

2) An ITP Equipment Status Monitoring procedure must be developed which will provide a consistent method for evaluating ITP equipment and component status and selected process parameters during an accident condition.

3) A shiftly vi al inspection of the tank exhaust fans must be performed per written procedure. Procedure shall require check off, signature, or data entry after visual inspection has been completed.

4) Assumed response times for diagnosis and placement of emergency purge ventilation equipment on the tank top are as follows: 10 hours to diagnose the event and determine that the emergency purge ventilation equipment needs to be installed and 4 hours to place the emergency purge ventilation equipment in position (not installed and operational) on the tank top.

a) The emergency purge ventilation equipment must be stored and maintained in a building that will survive a $.2 \mathrm{~g}$ earthquake or high wind event, along with all the peripheral equipment (including the installation procedures) necessary for their installation at tanks 48 and 49. (Configuration management practices and procedures must demonstrate that the installation procedures stored 
with the equipment are maintained to the latest revision.) This includes any special tools, flexible duct and consumables (e.g., duct tape) required for proper installation.

b) The storage location must be selected based on Waste Management personnel's demonstrated ability to move the emergency purge ventilation equipment from its storage location to the tank top within 4 hours under the anticipated post accident conditions. Waste Management personnel should assess the potential travel routes for potential obstructions to ensure accessibility of at least one of the routes following a seismic/high wind event.

c) The emergency purge ventilation equipment must be sized so that the equipment can be hand carried from its storage location to the tank top.

d) Two maintenance persons trained (via simulations) in the installation of the emergency purge ventilation equipment must be available on all shifts to move and install the purge equipment. Under emergency conditions, the maintenance personnel may be obtained from the Operations Support Center (OSC) located at the bottom of "the hill". Portable radio communications with the OSC must be available.

d) For operating conditions not classified as an emergency event, the Waste Management Maintenance department will have an established priority system in place to respond immediately, upon notification from Waste Management Operations, to a loss of ventilation event for ITP tanks 48 and 49.

e) Maintenance and Operations personnel must be trained (via simulations) to know where the emergency purge ventilation equipment is stored, who is responsible for access control to the equipment, how to place the equipment in position on the tank top, and how to hookup the equipment to the tanks.

f) The tank system operating procedures must identify the storage location of the emergency purge ventilation equipment.

5) The Operational Safety Requirements (OSRs) for In-Tank Precipitation Process will specify the conditions under which the emergency purge ventilation equipment should be hooked up to the riser.

6) The "Tank 48 System" System Operating Procedure (SOP) must incorporate the following:

a) The procedure must use nomenclature for the emergency purge ventilation equipment that is consistent with the nomenclature used in the OSR. 
b) The risers must be labeled in accordance with the facility or division labeling procedure. The procedures and sketches must also match the labeling standards used.

c) The procedures' and sketches' references to valve numbers, etc., must match the equipment tags in the field. (Currently, two to three different labels are identified in the procedures and sketches for a single valve.)

d) Diagrams must be included in the tank system operating procedure. (Currently, the operators must obtain the approved sketches to be used with the procedure from a separate location.)

e) The procedure must specify any special tools, equipment, or consumables (e.g., duct tape) that may be required for installation and hookup of the emergency purge ventilation equipment.

7) In order to allow for a recovery action if the emergency purge ventilation equipment were hooked up incorrectly, a flow indicator must be installed as a part of the emergency purge ventilation equipment unit.

8) Skilled personnel are available to perform all tasks. Skilled personnel must have completed training qualification and have six months or more on the job experience.

9) A tank operator must be available to monitor the installation of the emergency purge ventilation equipment by the maintenance personnel.

10)The OSR requires HP or Industrial Hygiene personnel to obtain a LFL analyzer reading using a portable, battery-operated LFL analyzer [Limiting Condition for Operation (LCO) 3.3.1.c Action c.2.1]. The battery-operated portable LFL analyzer must be stored and maintained in a building that will survive a $.2 \mathrm{~g}$ earthquake or high wind event. The "OSR Linking Document In-Tank Precipitation Process" must include a reference to the SW16.1-SOP-WTE-1, "General Tank System Operations" procedure under LCO 3.3.1.c in order to establish manual hydrogen monitoring.

\section{ANALYSIS METHOD AND CALCULATIONS}

The analysis method was based on NUREG/CR-1278-F, "Handbook of Human Reliability Analysis with Emphasis on Nuclear Power Plant Applications".

A task analysis was performed of the off normal procedure and standard operating procedure which lead the operator to align and start the emergency purge ventilation equipment following a loss of the ventilation system. (See Appendices A and B). The task analysis process consisted of the following data collection: 
1. Review of Safety Analysis Report

2. Review of draft emergency, off normal, and standard operating procedures

3. Review of system description documents

4. Review of On-the-Job Training and Student Study Guides

5. Review of Operational Safety Requirements for ITP

6. Interviews with subject matter experts (SMEs)

7. Walkdown of 241-82H control room

8. Walkdown of tank 48 equipment components required for portable fan operation

Following the analysis of each task, error probabilities and error factors (taken from data tables (Tables 20-1 through 20-27) in NUREG/CR-1278-F) were assigned to events that represented the operator responses.

To account for performance shaping factors, some human error probabilities (HEPs) were modified. For example, both onsite and offsite power are assumed to be unavailable following a seismic event. This means that no alarms (either from the Distributed Control System or the 7400B hardwired alarm panel) are available to aid the control room operators in diagnosis of the event. In order to adjust the HEP for reduced diagnostic aids, the upper bound value of the nominal diagnosis model (Figure 12-4 in NUREG/CR-1278-F) was used.

Recovery probabilities were determined by assessing task characteristics and crew behavior. The likelihood of recovery is typically improved by factors such as: task familiarity, alarms, and independent checking. For this analysis, the relationship among the Waste Management personnel (Maintenance, Operations, Health Protection, and Industrial Hygiene) is characterized by a model of dependence (NUREG/CR-1278-F, p.10-17). Tables in NUREG/CR-1278-F are presented in terms of positive dependence, which corresponds with a likelihood that an action will be followed by another action of similar accuracy. For tasks with high dependence a mistake is highly likely to be followed by another mistake. Actions with low dependence, on the other hand, result in opposite outcomes. For example, a mistake would be less likely to be followed by another mistake. Instead, a successful recovery would be more likely. Therefore, HEPs for recovery tasks were assigned using Table 20-21 of NUREG/CR-1278-F to approximate conditional HEPs for dependence levels given failure on the preceding task. In this analysis, dependence levels were assigned based on operator interactions. Examples of conditions for which low, moderate, and high dependence would be assessed in nuclear power plant control rooms are briefly described here with reference to the appropriate pages in NUREG/CR-1278-F.

1. Low dependence - assessed for interactions between two control room operators who are newly acquainted with one another. They have not yet developed confidence in one another and would consider the task requirements more 
independently. Greater care in checking each other's task would be taken. (page 10-17)

2. Moderate dependence - assessed between a shift supervisor and control room operators for tasks in which the supervisor is expected to interact with the operators. (page 10-17)

3. High dependence - usuall:' assessed between two control room operators for tasks in which they are supposed to interact. Checking each other's work tends to be more casual. (page 10-18)

After error probabilities were assigned, event trees were constructed. (See Figure

1.) The lettering system represents the following:

1. Task " $A$ " = the first task

2. Task "B" = the second task

3. $a$ = probability of successful performance of task " $A$ "

4. $\mathbf{A}=$ probability of unsuccessful performance of task "A"(Failure)

From each event tree, calculation formulas were derived. At the end of each path is a failure or a success probability. In this analysis, a given failure path probability $\left(\mathrm{F}_{\mathrm{i}}, \mathrm{i}=\right.$ path number) was determined by multiplying together each failure probability along the given path.

The method of calculating the error probability from the multiplication of the error branches is a short method that is simpler than the long method and results in slightly more conservative numbers. The longer method includes each success branch and recovery events in the calculation. The long method is more complex, but does not result in numbers which are statistically significant from the short method as long as the failure probabilities are much less than unity. (See NUREG/CR-1278-F p. 5-15.) To calculate the total failure probability (FT), all failure path probabilities were added together.

\section{RESULTS}

\section{Summary of Operator Actions in Event Tree}

The analysis assumes a seismic event initiator leading to establishing air based ventilation on the ITP processing tanks 48 and 49 . At the time of this analysis only the tanks and the emergency purge ventilation equipment are seismically qualified. Consequently, onsite and offsite power is assumed to be unavailable and all operator control actions are to be performed locally on the tank top. A task analysis was performed for this task and is documented in Appendix B. The task analysis was done for the Off Normal Procedure (ONP), "Loss of Ventilation" and the Standard Operating Procedure (SOP), "Tank 48 System". Only those sections directly applicable to the alignment and startup of the emergency purge ventilation equipment on tank 48 were analyzed. 
The first step is the diagnosis step (Task "A"). Due to the loss of all power, none of the alarms on the 7400B hardwired alarm panel in the 241-82H control room are available to aid the control room crew in their diagnosis of the event. The analysis assumes that the crew is cognizant that a seismic event has occurred due to ground movement and/or notification from the Emergency Operations Center. This combined with the loss of power will trigger the crew to perform walkdowns of the tanks to assess the tanks' conditions. Operational Safety Requirements (OSRs) state that the emergency purge ventilation equipment must be located (but not installed and operational) at the tanks within 14 hours after loss of the ventilation system. This results in the crew having approximately 10 hours to diagnose the event and determine the need to go to air based ventilation using the emergency purge equipment. A recovery for this initial failure to diagnose the need for the emergency purge ventilation equipment is a visual inspection of the tank exhaust fans that is required to be performed shiftly by procedure (Task " $B$ ").

The next step is to initiate the SOP, "Tank 48 System" as directed by the Off Normal Procedure "Loss of Ventilation" (Task "C"). Again, a recovery for failure to initiate this step is the shiftly visual inspection of the tank exhaust fans (Task "B"). After determining that the tank exhaust fans are inoperable, the tank operator must notify maintenance to attempt to establish emergency purge ventilation. Maintenance must move the emergency purge ventilation equipment into position at the tanks and hookup the equipment to the tank top riser (Task "D"). There are several recoveries for failure to hookup the emergency purge equipment correctly. The recoveries are as follows:

1. A second maintenance person is available who works with the first maintenance person on the installation of the emergency purge ventilation equipment (Task " $E ")$. This serves as a type of check, however, it is not a strong one since they are working simultaneously on the hookup.

2. A tank operator is available who is responsible for verifying that the hookup procedures are performed correctly (Task " $G$ ").

3. A flow indicator on the emergency purge ventilation equipment is available to alert both the maintainers and the tank operator if the equipment is hooked up improperly (Task "H").

4. Written procedures require Health Protection or Industrial Hygiene personnel to analyze the Lower Flammability Limit (LFL) using portable self-powered LFL analyzers (Task "J"). The change in the percentage LFL is available to alert both the maintainers and the tank operator if the equipment is hooked up improperly. 
Recoveries 3 and 4 would result in an additional step for operations and maintenance personnel to diagnose and correct the error made during hookup (Task "I").

Appendix C provides a timeline representation of the sequence of events for establishing air based ventilation using the emergency purge ventilation equipment.

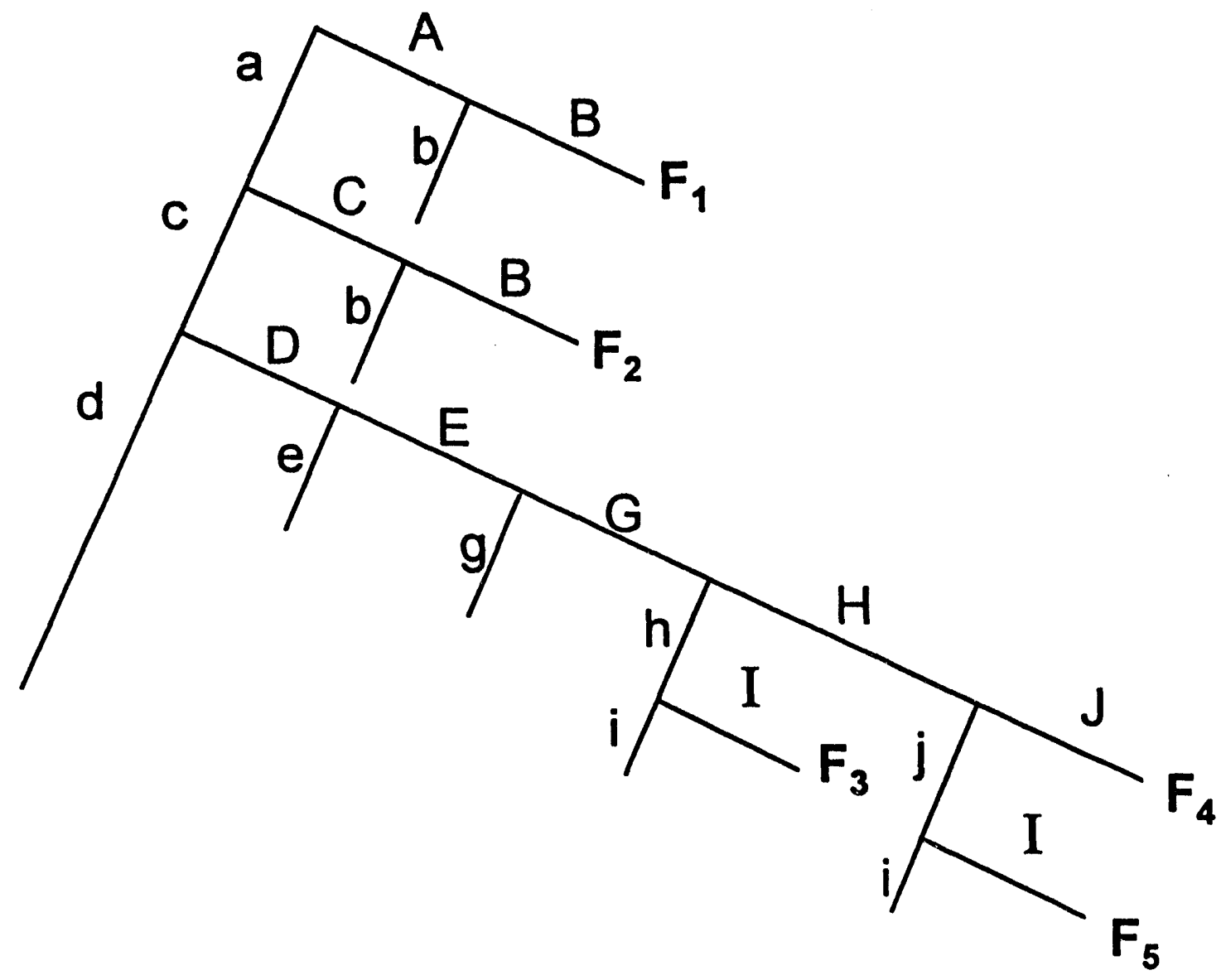

Figure 1. HRA Event Tree for Align and Start Emergency Purge Ventilation Equipment on In-Tank Precipitation Tank 48 or 49 After a Seismic Event 


\title{
ALIGN AND START EMERGENCY PURGE VENTILATION EQUIPMENT ON IN-TANK PRECIPITATION TANK 48 OR 49 AFTER A SEISMIC EVENT
}

\author{
HIRA Event Tree Branch Definitions
}

"A "= Diagnosis

$$
\mathrm{HEP}=6.0 \mathrm{E}-4 \mathrm{EF}=30
$$

Figure 12-4, Nominal Diagnosis Model, Time $T=600$ minutes, upper bound Based on the Operational Safety Requirements (OSRs), the operators have 10 hours available for diagnosis of this event. The OSR requires the emergency purge ventilation equipment to be in place on the tank top within 14 hours following loss of ventilation. Time estimates from SMEs indicated 4 hours would be required for movement from storage and placement of the equipment on the tank top. (See Appendix A.) The upper bound is used due to loss of power and the unavailability of alarms to aid diagnosis. Assumptions \# 2 and 8

\section{"B" = Visual Inspection Performed Shiftly, Recovery Factor} $\mathrm{HEP}=.001 \mathrm{EF}=3$

Table 20-6, item 2

Stress modifiers from table 20-16 are not assigned due to the length of time available ( 3 days) for recovery from this event. The stress tables in NUREG/CR-1278-F are typically examining reactor control room operator mitigating actions that must be performed in a relatively short period of time ( $<2$ hours after the initiating event). (See NUREG/CR-1278-F, Figure 17-2, p. 17-15.)

Assumptions \# 3 and 8

$$
\begin{aligned}
& =\text { C" = Initiate Standard Operating Procedure } \\
& \text { HEP }=.003 \text { EF }=3 \\
& \text { Table 20-7, item } 2
\end{aligned}
$$

Initiate procedure SW16.1-SOP-WTE(48)-1, Tank 48 System as directed by procedure SW16.3-ONP-008. The error is failing to determine the need to go to the SOP because of omitting a step from the long list of tasks to be performed in the ONP.

\section{Assumption \# 8}

Note: Failure to transport, to the tank top, all of the emergency purge ventilation equipment components and tools required for installation is not modeled as an error. Failure to transport is considered to be the same action as failing to initiate the corrective action, the standard operating procedure.

Failure to follow a procedure never previously implemented is not modeled as an error since an explicit requirement exists to train on and practice the written installation procedure via simulations on a periodic basis. The simulated 
practice exercises coupled with periodic maintenance requirements to install portable exhausters requires no adjustment of the HEP value.

\section{"D" = Maintainer \#1 Hookup Emergency Purge Ventilation Equipment} $\mathrm{HEP}=.003 \mathrm{EF}=3$

Table 20-13, item 2

Table 20-13, Selection Errors for Locally Operated Valves, used due to similarity with selection of riser connections. Proper labeling of riser connections is assumed. This part of the task analysis (see Appendix B) differs slightly from the proposed emergency purge ventilation equipment. The proposed equipment will be a portable unit capable of being hand carried from storage to the tank top by one person. The installation will consist of hooking up the unit directly to the riser. The unit will not be connected to the exhaust stack (as shown in the task analysis) but will exhaust the tank air directly to the atmosphere.

Assumptions \# 4, 5, 6, and 8

Note: Failure to find all of the emergency purge ventilation equipment components and tools required for installation is not modeled as an error since an explicit requirement exists to store and maintain all of the required components and tools in the same location.

Failure to correctly install the emergency purge ventilation equipment was not modeled as an error since the simple installation required is assumed to be "skill-of-the-craft".

Failure to access a riser is not modeled since several risers are to be identified as acceptable locations for hookup of the emergency purge ventilation equipment. At least one riser is assumed to be accessible.

"E" = Maintainer \#2 Hookup Emergency Purge, Recovery Factor $\mathrm{CHEP}=.5 \mathrm{EF}=2$

Table 20-21, item 4a (High Dependence)

High dependence is assigned due to the maintainers' interaction with one another while performing this task. The checking of each other's actions would tend to be more casual. (See NUREG/CR-1278-F, p. 10-18.) Assumption \# 8

"G" = Tank Operator Instructing/Verifying Hookup, Recovery Factor CHEP $=.05$ Lower bound $=.015 /$ Upper bound $=.15$

Table 20-21, item 2a (Low Dependence)

Low dependence is assigned based on interviews with SMEs and observations made during walk-throughs. Since the tank operators and maintenance personnel typically do not work closely together, the tank operator will be much 
more vigilant while overseeing the maintainers' hookup of the emergency purge ventilation equipment. (See NUREG/CR-1278-F, p.10-17, 18-6, 18-7.)

Assumptions \# 8 and 9

"H" = Read Flow Indicator, Recovery Factor

CHEP $=.15$ Lower bound $=.04 /$ Upper bound $=.5$

Table 20-21, item 3a (Moderate Dependence)

Moderate dependence is assigned since the task is being performed by the maintainers/operator responsible for hookup of the equipment. Moderate dependence is assigned when there is an obvious relationship between performance on one task and on a subsequent task and the relationship is greater (i.e., the flow indicator is being read by the people responsible for hookup of the emergency purge ventilation equipment) than low dependence would imply. (See NUREG/CR-1278-F, p. 10-17.)

Assumption \# 7

"I" = Diagnosis

$\mathrm{HEP}=1.0 \mathrm{E}-5 \mathrm{EF}=30$

Table 20-3, item 6

Diagnosis time of approximately 24 hours to locate error in hookup \& repair.

The first attempt to establish air based ventilation covers a time span of approximately 17 hours. The nominal diagnosis model addresses diagnosis HEPs for time periods up to and including 24 hours following an initiating event. Therefore, 24 hours is assumed since the operators have a total of 72 hours following the seismic event to establish air based ventilation. Assumptions \# 1 and 8

"J" = Analyze LFL Using Portable LFL Analyzer, Recovery Factor CHEP $=.05$ Lower bound $=.015 /$ Upper bound $=.15$

Table 20-21, item 2a (Low Dependence)

Low dependence is assigned since this task is performed by either HP or Industrial Hygiene (IH) personnel. HP and/or IH would consider their task requirements more independently from Operations and Maintenance. HP and/or IH operate separately from the maintainers/operator performing the hookup. (See NUREG/CR-1278-F, p. 10-17, 18-6, 18-7.) The assignment of a CHEP of .05 is more conservative than the assignment used by Swain in table 20-22. This is actually a checking task involving a hands-on activity (e.g., using an instrument to obtain a measurement) and, per table 20-22, would be assigned a HEP of .01. Swain states that the performance level of the checker would approach that of the original operator (NUREG/CR-1278-F pp. 19-5 \& 19-6). However, the more conservative estimate of .05 seemed more appropriate in this analysis due to the number of recovery factors being considered.

Assumption \# 10 


\section{CALCULATION OF FAILURE PROBABILITIES:}

$$
\begin{aligned}
& \mathrm{F} 1=\mathrm{AB}=(6.0 \mathrm{E}-4)(.001)=6.0 \mathrm{E}-7 \\
& \mathrm{~F} 2=\mathrm{CB}=(.003)(.001)=3.0 \mathrm{E}-6 \\
& \mathrm{F3}=\mathrm{DEGI}=(.003)(.5)(.05)(1.0 \mathrm{E}-5)=7.5 \mathrm{E}-10 \\
& \mathrm{~F} 4=\mathrm{DEGHJ}=(.003)(.5)(.05)(.15)(.05)=5.62 \mathrm{E}-7 \\
& \mathrm{F5}=\mathrm{DEGHI}=(.003)(.5)(.05)(.15)(1.0 \mathrm{E}-5)=1.125 \mathrm{E}-10 \\
& \mathrm{~F}_{\text {Total }}=\mathrm{F} 1+\mathrm{F} 2+\mathrm{F} 3+\mathrm{F} 4+\mathrm{F} 5=4.1628625 \mathrm{E}-6=4.2 \mathrm{E}-6
\end{aligned}
$$

\section{CONCLUSIONS}

The human error probability for establishing air based ventilation using the emergency purge ventilation equipment on In-Tank Precipitation processing tanks 48 and 49 after a failure of the nitrogen purge system following a seismic event is 4.2E-6. This HEP is a median value on the lognormal scale. It is important to note that this result is predicated on the implementation of all of the assumptions listed in the "Assumptions" section of this report. This analysis was not based on the current conditions in ITP. The analysis is to be used as a tool to aid ITP operations personnel in achieving the training, procedural, and operational goals outlined in this document. If all of the assumptions are implemented as specified before startup, then the HEP of 4.2E-6 is valid. If any of the assumptions are not implemented, then a reanalysis of the HEP must be performed.

\section{Other Recommendations}

In the course of conducting this analysis, some miscellaneous human factors discrepancies were noted that should be addressed by ITP operations.

1. 7400B Hardwire Alarm Panel needs to be rearranged and prioritized. The operators need to be able to easily identify the highest priority and "first in" alarms received. Also, if the alarms are to continue to be indexed in the Alarm Response Procedures by physical grid location number, this number needs to be added to the alarm plate.

2. There are three gauges located on the side of the HEPA building on tank 48 that are read by ITP personnel. The gauges are the demister delta p, tank vacuum, and the purge filter delta $p$. The operator has to climb the platform stairs to get to the gauges. The demister delta $p$ and tank vacuum can be read from a squatting position, but to get an accurate purge filter delta $p$ reading, the 
operator has to climb off of the platform and precariously straddle some I-beams to read the gauge. (I observed an operator doing this during a walkdown of the tanks.) Operations should consider relocating these gauges to improve operator access.

3. Valves, particularly valves that may require throttling actions, should have some type of "per cent open" indication for the operator. Existing procedures for adjusting purge flow after establishing air based ventilation require throttling of an emergency air purge inlet bypass valve and the primary purge emergency filter inlet isolation valve. The air purge inlet valve only has a rising stem : ndication. The emergency filter inlet isolation valve has a dial indicator with three unlabeled hash marks for indicating per cent open.

4. The ITP procedure system as a whole needs to be upgraded and is currently undergoing revision. NUREG/CR-1278-F offers a list of references of NUREGs by R.L. Brune and M. Weinstein that could be helpful in evaluating the procedures.

5. Ideally, some type of simulator would provide the optimal training skills to the operator. Currently, the operators have no "hands on" experience with the tank operating and control systems except under limited supervision with the real systems on the job. The opportunity to learn the systems "hands on" in a simulated environment would greatly enhance operator skills. At a minimum, a simulated DCS/PLC system and requisite training program should be implemented. 


\section{REFERENCES}

Distributed Control System (DCS) System Description, NWIOG231.H0600, Revision 0, March 1993.

Gupta, M. K., T.E. Britt, Bonnie J. Shapiro, and Andrea Beyrer. Accident Analysis for In-Tank Precipitation Process Nitrogen Purge System, SWRC-TR-93-169, Westinghouse Savannah River Company, Aiken, South Carolina, April 1, 1993.

High Level Waste Processing Cycle 7 Student Study Guide, Westinghouse Savannah River Company, Aiken, South Carolina, March 1993.

High Level Wa'te Processing Cycle 8 Student Study Guide, Westinghouse Savannah River Company, Aiken, South Carolina, April 1993.

Operational Safety Requirements In-Tank Precipitation Process Savannah River Site, WSRC-RP-90-1124, Revision 1, Westinghouse Savannah River Company, Aiken, South Carolina, April 1993.

OSR Linking Document In-Tank Precipitation Process Savannah River Site, WSRCRP-93-XXX, Revision 0 (DRAFT), Westinghouse Savannah River Company, Aiken, South Carolina, May 1993.

Safety Analysis Report, Liquid Radioactive Waste Handling Facilities: Addendum 1, Additional Analysis for DWPF Feed Preparation by In-Tank Processing, DPSTSA-200-10, SUP 18, DOE Approval Draft, July 1992.

Swain, Alan D. Accident Sequence Evaluation Program Human Reliability Analysis Procedure, NUREG/CR-4772, Sandia National Laboratories, Albuquerque, New Mexico, February, 1987.

Swain, Alan D. and Henry E. Guttmann. Handbook of Human Reliability Analysis with Emphasis on Nuclear Power Plant Applications, NUREG/CR1278-F, Sandia National Laboratories, Albuquerque, New Mexico, August, 1983.

SW1X.X, Revision 0, "ITP Equipment Status Monitoring" DRAFT 7/8/93.

SW16.1-SOP-WTE-1, Revision 0, "General Tank System Operations" DRAFT $7 / 93$.

SW16.1-SOP-WTE(48)-1, Revision 0, "Tank 48 System" DRAFT 4/30/93.

SW16.3-ONP-008, Revision 0, "The Savannah River Site ITP Facility Operating Manual Off Normal Procedure, Loss of Ventilation" DRAFT 4/30/93. 
SW16.4-EOP-003, Revision 0, "The Savannah River Site ITP Facility

Operating Manual Emergency Operating Procedure, Earthquake" DRAFT 4/30/93.

Waste Tank Purge and Ventilation System Description, NWVIOG229.H0300, Revision 0, Westinghouse Savannah River Company, Aiken, South Carolina, October 1992.

Waste Tank Systems Description, NWIOG229.H0100, Revision 0, Westinghouse Savannah River Company, Aiken, South Carolina, October 1992.

7400B (Hardwire) Alarm Panel System Description, NWIOG231.H0800, Revision 0, Westinghouse Savannah River Company, Aiken, South Carolina, March 1993. 


\section{APPENDIX A: TIME ESTMMATES}

(Note: This information was based on the original task analysis data from revision 0 of CALC-NOTE, SRT-HFE-93-9004. For revision 0, the emergency purge ventilation equipment was assumed to be fans mounted on skids that would require some type of transport and lifting equipment to set in place on the tank top.)

Since time to establish air based ventilation before exceeding the LFL is 3 days, the time to perform the individual tasks is not a critical parameter. The following time estimates for completion of large subsets of tasks associated with establishing air based ventilation were obtained from interviews with SMEs. The time estimates from the SMEs were doubled to be used in the HRA. (See NUREG/CR-4772, "Accident Sequence Evaluation Program Human Reliability Analysis Procedure", p. 8-4.)

\begin{tabular}{|l|l|l|l|}
\hline TASK & $\begin{array}{l}\text { SME TMME } \\
\text { ESTMMATE }\end{array}$ & $\begin{array}{l}\text { FRA TMME } \\
\text { ESTMMATE }\end{array}$ & $\begin{array}{l}\text { REVISED } \\
\text { HRA TMME } \\
\text { ESTIMATE } \\
\text { (REV.1) }\end{array}$ \\
\hline $\begin{array}{l}\text { Retrieve fans from } \\
\text { storage and place in } \\
\text { position on skid }\end{array}$ & $45 \mathrm{~min}$. to $1 \mathrm{hr}$. & $2 \mathrm{hrs.}$ & \\
\hline $\begin{array}{l}\text { Hookup and start skid- } \\
\text { mounted fans }\end{array}$ & $1 \mathrm{hr}$. to $1.5 \mathrm{hrs}$. & $3 \mathrm{hrs}$. & \\
\hline $\begin{array}{l}3 \text { operators walk- } \\
\text { down equipment } \\
\text { following seismic } \\
\text { event }\end{array}$ & $.5 \mathrm{hr}$. & $1.0 \mathrm{hr}$. & \\
\hline $\begin{array}{l}\text { Adjust purge flow after } \\
\text { startup fans }\end{array}$ & $1 \mathrm{hr}$. & $2 \mathrm{hrs}$. & \\
\hline
\end{tabular}

* Note: This new time estimate was derived during the Engineering and Projects Division's design specifications phase for the emergency purge ventilation equipment. 


\section{APPENDIX B: TASK ANALYSES}

(Note: This task analysis data is from revision 0 of CALC-NOTE, SRT-HFE-939004. For revision 0 , the emergency purge ventilation equipment was assumed to be fans mounted on skids that would require some type of transport and lifting equipment to set in place on the tank top. Also, several valve alignments, both on the tank top and on the fan unit, were assumed to be required. For revision 1, the fans are portable (can be hand carried) and no valve alignments are required.) 
TASK ANATYSIS OF SW16.3-ONP-008 OPERATOR ACTIOIS FOR STARIUP OF SKID-MOUMHD FAMS

\begin{tabular}{|c|c|c|c|c|c|c|c|}
\hline 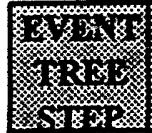 & 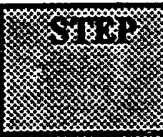 & 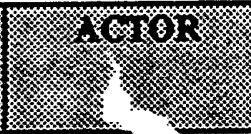 & (1) & 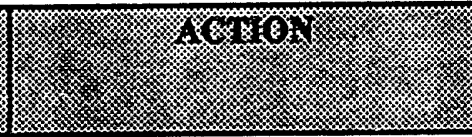 & $H^{2}$ & (1) & 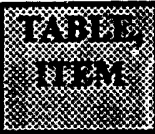 \\
\hline$A$ & & $\begin{array}{l}241-82 \mathrm{H} \text { Control } \\
\text { Room Operator }\end{array}$ & $7400 \mathrm{~B}$ alarm panel & $\begin{array}{l}\text { Initiate SW16.3-ONP-008, Loss } \\
\text { of Ventilation, Off Normal } \\
\text { Procedure }\end{array}$ & 0.0006 & 30 & $\begin{array}{l}\text { Figure } 12- \\
4, \text { upper } \\
\text { bound }\end{array}$ \\
\hline & & $\begin{array}{l}\text { 241-82H Control } \\
\text { Room Operator }\end{array}$ & $7400 \mathrm{~B}$ alarm panel & $\begin{array}{l}\text { Verify Waste Tank Nitrogen } \\
\text { Purge Ventilation is lost }\end{array}$ & & & \\
\hline B & 测 & $\begin{array}{l}241-82 \mathrm{H} \\
\text { Surveillance } \\
\text { Operator }\end{array}$ & Purge Exhaust Fan 7 & $\begin{array}{l}\text { Determine if power available to } \\
\text { tank } 48 \text { primary purge fan } 7 \\
\text { motor starter (attempt to start } \\
\text { locallv) }\end{array}$ & 0.001 & 3 & $20-6,2$ \\
\hline $\mathbf{B}$ & . & $\begin{array}{l}241-82 \mathrm{H} \\
\text { Surveillance } \\
\text { Operator }\end{array}$ & Purge Exhaust Fan 8 & $\begin{array}{l}\text { Determine if power available to } \\
\text { tank } 48 \text { primary purge fan } 8 \\
\text { motor starter (attempt to start } \\
\text { locallv) }\end{array}$ & & & \\
\hline & $y / x_{y}$ & $\begin{array}{l}241-82 \mathrm{H} \\
\text { Operator \#1 }\end{array}$ & All ITP Equipment & $\begin{array}{l}\text { Inspect for failed or damaged } \\
\text { equipment }\end{array}$ & & & \\
\hline & \% & $\begin{array}{l}241-82 \mathrm{H} \\
\text { Operator \#2 }\end{array}$ & All ITP Equipment & $\begin{array}{l}\text { Inspect for failed or damaged } \\
\text { equipment }\end{array}$ & & & \\
\hline & m & $\begin{array}{l}241-82 \mathrm{H} \\
\text { Operator \#3 }\end{array}$ & All ITP Equipment & $\begin{array}{l}\text { Inspect for failed or damaged } \\
\text { equipment }\end{array}$ & & & \\
\hline & \% & $\begin{array}{l}241-82 \mathrm{H} \\
\text { Surveillance }\end{array}$ & Ventilation dampers & $\begin{array}{l}\text { Verify damper lineup permits } \\
\text { operation }\end{array}$ & & & \\
\hline
\end{tabular}


TASK ANALYSIS OF SW16.3-ONP-008 OPERATOR ACTIONS FOR STARTUP OF SKID-MOUNHED FANS

\begin{tabular}{|c|c|c|c|c|c|}
\hline 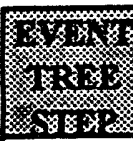 & 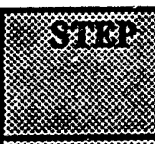 & 年 & 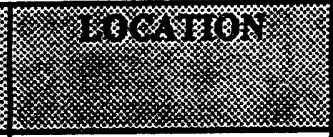 & (1) & (2) \\
\hline A & & $\begin{array}{l}\text { TK48 PRIMARY PURGE NOT } \\
\text { RUNNING }\end{array}$ & 241-82H control room & $600 \mathrm{~min}$. & $\begin{array}{l}\text { Omission - failure to } \\
\text { correctly diagnose event }\end{array}$ \\
\hline & & $\begin{array}{l}\text { TK48 LOW VACUUM, NITROGEN } \\
\text { DISTRIBUTION SYSTEM LOW } \\
\text { HEADER PRESSURE, NITROGEN } \\
\text { STORAGE SYSTEM FIRST } \\
\text { STANDBY ON LINE, NITROGEN } \\
\text { STORAGE SYSTEM SECOND } \\
\text { STANDBY ON LINE, NIGROGEN } \\
\text { STORAGE SYSTEM LOW TANK } \\
\text { LEVEL }\end{array}$ & $241-82 \mathrm{H}$ control room & & \\
\hline B & 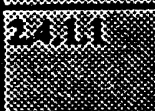 & $\begin{array}{l}\text { Fan noise if it starts up and procedure } \\
\text { step checked off }\end{array}$ & $\begin{array}{l}\text { Top of tank } 48 \text { at the } \\
\text { exhaust stack }\end{array}$ & & $\begin{array}{l}\text { Omission - failure of } \\
\text { administrative control }\end{array}$ \\
\hline $\mathbf{B}$ & 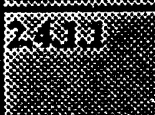 & $\begin{array}{l}\text { Fan noise if it starts up and procedure } \\
\text { step checixed off }\end{array}$ & $\begin{array}{l}\text { Top of tank } 48 \text { at the } \\
\text { exhaust stack }\end{array}$ & & \\
\hline & $\frac{1}{2 x}$ & $\begin{array}{l}\text { No fan noise, leakage due to line } \\
\text { breaks, structural damage, gauges off- } \\
\text { scale. }\end{array}$ & ITP & & \\
\hline & 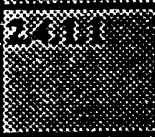 & $\begin{array}{l}\text { No fan noise, leakage due to line } \\
\text { breaks, structural damage, gauges off- } \\
\text { scale }\end{array}$ & ITP & & \\
\hline & & $\begin{array}{l}\text { No fan noise, leakage due to line } \\
\text { breaks, structural damage, gauges off- } \\
\text { scale. }\end{array}$ & IIP & & \\
\hline & $y^{\prime}$ & Pertinent dampers are open & $\begin{array}{l}\text { Top of tank } 48 \text { at the } \\
\text { exhaust stack }\end{array}$ & & \\
\hline
\end{tabular}


TASK ANAIYSIS OF SW16.3-ONP-008 OPERATOR ACTIONS FOR STARTUP OF STID-MOUITHD FANS

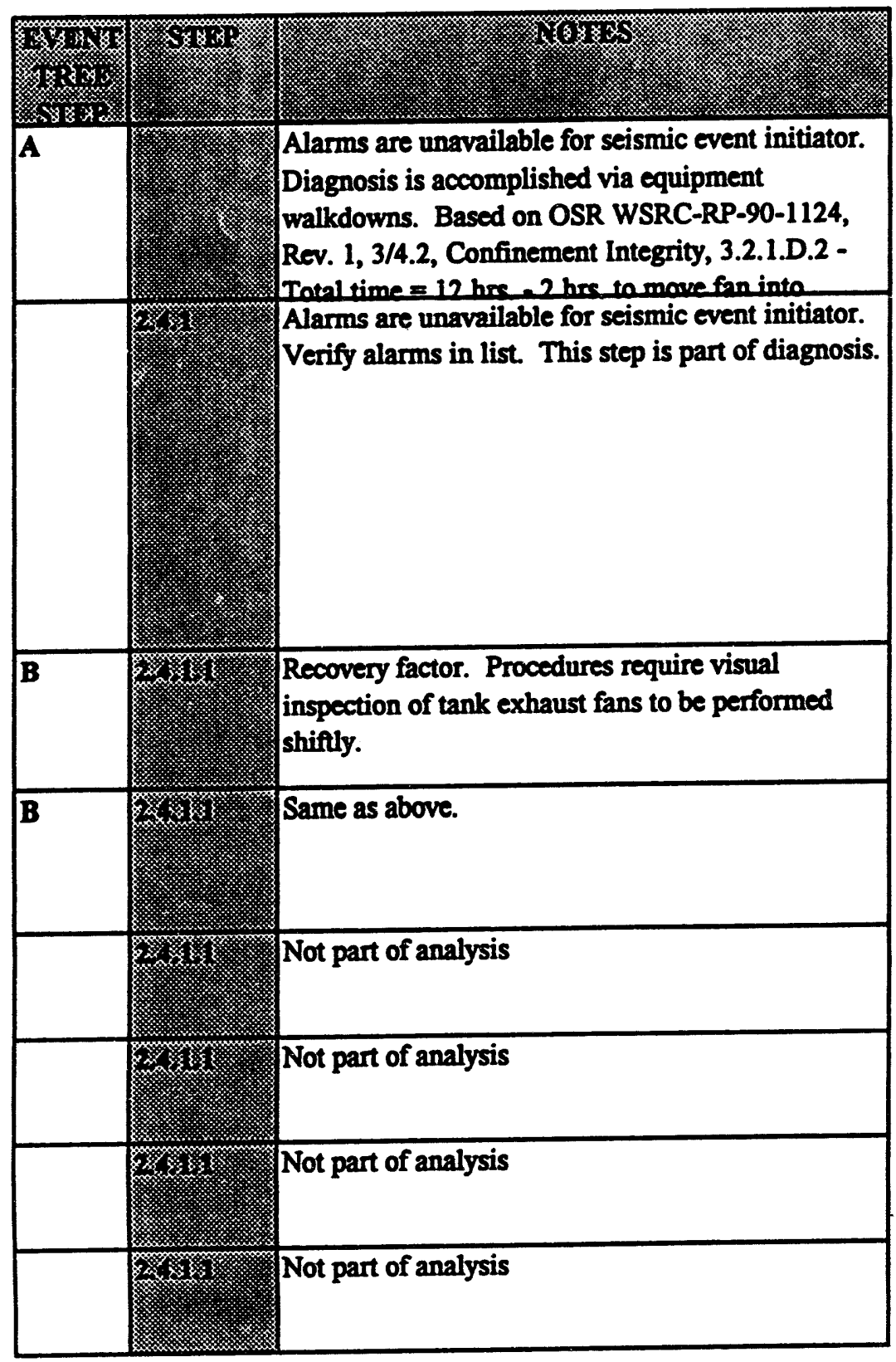


TASK ANALYSIS OF SW16.3-ONP-008 OPERATOR ACTIONS FOR STARIYP OF SKID-MOUNTED FANS

\begin{tabular}{|c|c|c|c|c|c|c|c|}
\hline 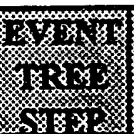 & $\frac{1}{2.18}$ & 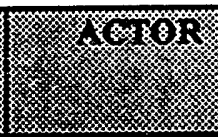 & 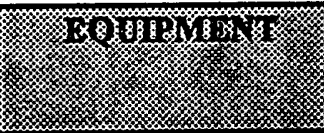 & 6. & 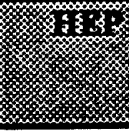 & 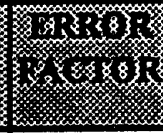 & 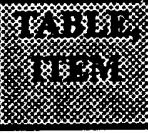 \\
\hline & 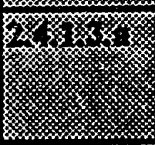 & $\begin{array}{l}241-82 \mathrm{H} \\
\text { Surveillance } \\
\text { Operator }\end{array}$ & Nitrogen purge system & $\begin{array}{l}\text { If } \mathrm{N} 2 \text { not available, request } \\
\text { permission to establish air based } \\
\text { ventilation }\end{array}$ & & & \\
\hline C & 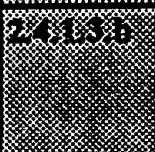 & $\begin{array}{l}241-82 \mathrm{H} \\
\text { Surveillance } \\
\text { Operator }\end{array}$ & & $\begin{array}{l}\text { Initiate SW16.1-SOP-WTE(48)- } \\
1 \text { to start portable purge exhaust } \\
\text { unit }\end{array}$ & 0.003 & 3 & $20-7,2$ \\
\hline
\end{tabular}


TASK ANALYSIS OF SW16.3-ONP-008 OPERATOR ACTIONS FOR STARTUP OF SRID-MOUNIED FANS

\begin{tabular}{|c|c|c|c|c|c|}
\hline 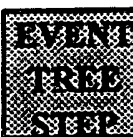 & 48 & H11: & $\frac{1}{2 \pi}$ & 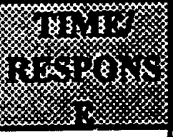 & 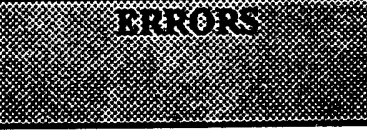 \\
\hline & 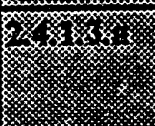 & $\begin{array}{l}\text { No nitrogen flow (pipes are not cold to } \\
\text { the touch) }\end{array}$ & Top of tank 48 & & \\
\hline $\mathbf{C}$ & z & & & & $\begin{array}{l}\text { Omission - failure to } \\
\text { perform step in procedure }\end{array}$ \\
\hline
\end{tabular}


TASK ANALYSIS OF SW16.3-ONP-008 OPERATOR ACTIONS FOR STARTUP OF SKID-MOUNHED FANS

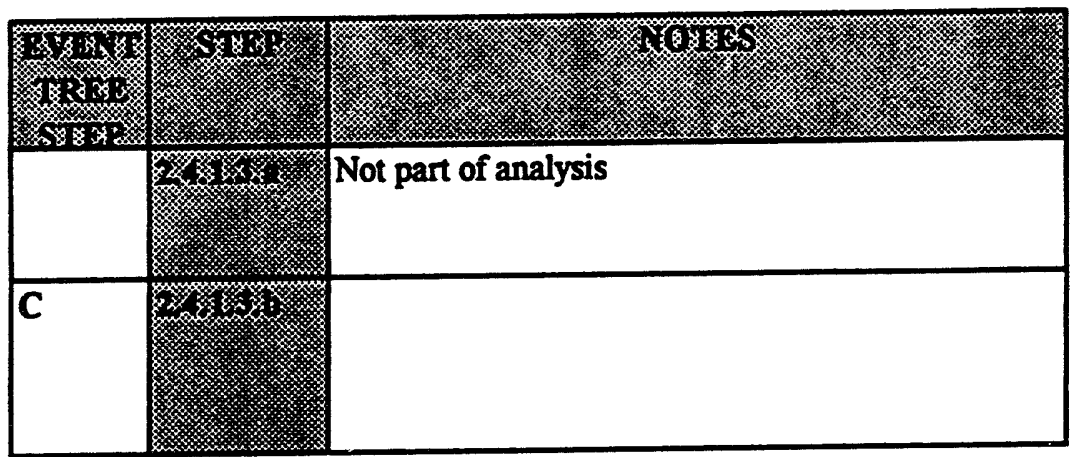


TASK ANAIYSIS OF SW16.1-SOP-WTE(48)-1 OPERATOR ACTIONS FOR STARTUP OF SKID-MOUNHED FAMS

\begin{tabular}{|c|c|c|c|c|c|c|c|}
\hline$\frac{x+3}{x+3}$ & 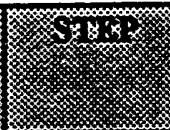 & (3) & 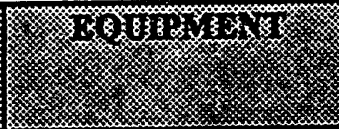 & (1) & 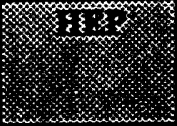 & 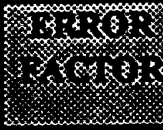 & 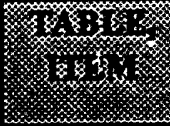 \\
\hline G & 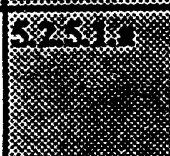 & WM tank operator & $\begin{array}{l}\text { Portable purge exhaust } \\
\text { unit skid }\end{array}$ & $\begin{array}{l}\text { Instruct WMM to move portable } \\
\text { purge exhaust unit into position } \\
\text { on skid }\end{array}$ & 0.05 & & $20-21,2 a$ \\
\hline & w & WM tank operator & HEPA filter & Verify HEPA filter DOP tested & & & \\
\hline & Swiving & WM tank operator & $\begin{array}{l}\text { 241-82H control room } \\
\text { logbook }\end{array}$ & Record DOP test results & & & \\
\hline & 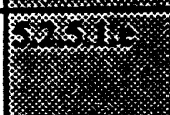 & $\begin{array}{l}\text { WM maintenance } \\
\text { \#1 \& } 2\end{array}$ & H \& V plug & $\begin{array}{l}\text { Verify H \& V plug installed in } \\
\text { C1 Riser }\end{array}$ & & & \\
\hline D & m. & $\begin{array}{l}\text { WM maintenance } \\
\text { \#1 }\end{array}$ & Blank flange & Remove blank flange & 0.003 & 3 & $20-13,2$ \\
\hline $\mathbf{E}$ & & $\begin{array}{l}\text { WM maintenance } \\
\text { *2 }\end{array}$ & & & 0.5 & & $20-21,4 a$ \\
\hline $\mathbf{D}, \mathbf{E}$ & (1) & $\begin{array}{l}\text { WM maintenance } \\
\begin{array}{ll}\text { 1 \& } 2\end{array}\end{array}$ & Flexible duct line & $\begin{array}{l}\text { Attach flexible duct line at fan } \\
\text { outlet of portable purge exhaust } \\
\text { unit }\end{array}$ & & & \\
\hline $\mathbf{D}, \mathbf{E}$ & 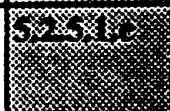 & $\begin{array}{l}\text { WM maintenance } \\
\text { \#1 \& } 2\end{array}$ & Blank flange & Remove blank flange & & & \\
\hline $\mathbf{D}, \mathbf{E}$ & 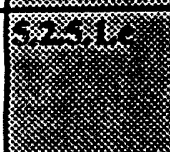 & $\begin{array}{l}\text { WM maintenance } \\
\text { \# } 1 \text { \& } 2\end{array}$ & Flexible duct line & $\begin{array}{l}\text { Attach other end of flexible duct } \\
\text { line to permanent purge exhaust } \\
\text { stack }\end{array}$ & & & \\
\hline $\mathbf{D , E}$ & \% & WM maintenance & Blank flange & Remove blank flange & & & \\
\hline
\end{tabular}


TASK AMALYSIS OF SW16.1-SOP-WIE(48)-1 OPERATOR ACTIONS FOR STARTUP OF SKID-MOUNTED FAMS

\begin{tabular}{|c|c|c|c|c|c|}
\hline 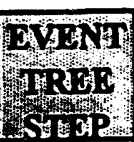 & Snpm & 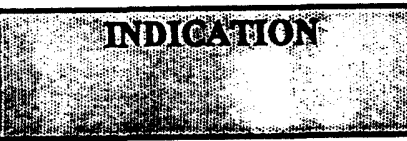 & 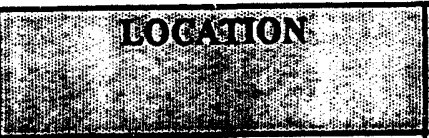 & 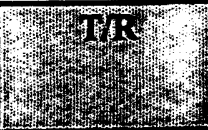 & Mrark \\
\hline G & & $\begin{array}{l}\text { Unit is positioned on skid at } \\
\text { tank } 48\end{array}$ & $\begin{array}{l}\text { Concrete slab skid adjacent to- } \\
\text { top of tank } 48 \text { next to tank } \\
\text { purge enclosure }\end{array}$ & 2 hrs. & \\
\hline & $5 x^{2}=10$ & $\begin{array}{l}\text { DOP tag on filter is up-to- } \\
\text { date }\end{array}$ & $\begin{array}{l}\text { Portable purge exhaust unit } \\
\text { skid }\end{array}$ & & \\
\hline & 3ring & $\begin{array}{l}\text { DOP test results written in } \\
\text { logbook }\end{array}$ & 214-82H control room & & \\
\hline & $7^{5}+16$ & $\begin{array}{l}\mathrm{H} \& \mathrm{~V} \text { plug in place in } \mathrm{Cl} \\
\text { riser }\end{array}$ & Cl riser on top of tank 48 & & No error \\
\hline $\mathbf{D}$ & S1356 & Flange is removed & $\begin{array}{l}\text { Fan outlet on portable purge } \\
\text { exhaust unit at connection D } \\
\text { (sketch 138-8-H-WR-204) }\end{array}$ & & $\begin{array}{l}\text { Commission - failure to } \\
\text { select correct flanges }\end{array}$ \\
\hline $\mathbf{E}$ & & & & & \\
\hline $\mathbf{D , E}$ & 53610 & Duct line is connected & $\begin{array}{l}\text { Fan outlet on portable purge } \\
\text { exhaust unit at connection D } \\
\text { (sketch 138-8-H-WR-204) }\end{array}$ & & \\
\hline $\mathbf{D , E}$ & 525 & Flange is removed & $\begin{array}{l}\text { Connection E on permanent } \\
\text { purge exhaust stack (sketch } \\
\text { 138-8-H-WR-204) }\end{array}$ & & \\
\hline $\mathbf{D , E}$ & Fis & Duct line is connected & $\begin{array}{l}\text { Connection E on petsianent } \\
\text { purge exhaust scack (sketch } \\
138-8-H-W K-204 \text { ) }\end{array}$ & & \\
\hline$\overline{D, E}$ & Fos & Flange is removed & $\begin{array}{l}\text { Connectior B (sketch 138-8- } \\
\text { H-WR-204) }\end{array}$ & & \\
\hline
\end{tabular}




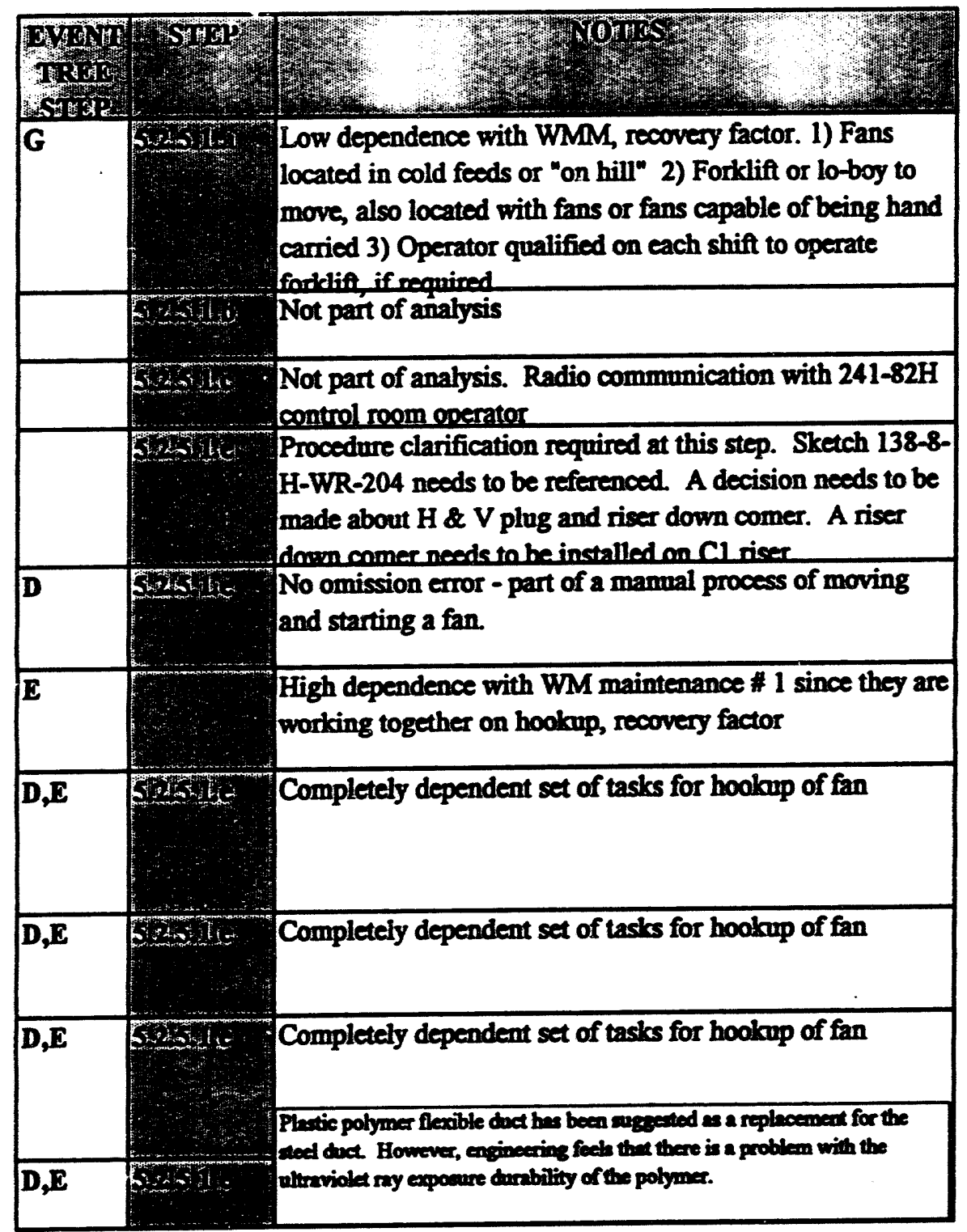




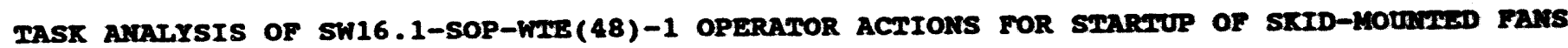

\begin{tabular}{|c|c|c|c|c|c|c|c|}
\hline$\frac{1}{464}$ & (3) & 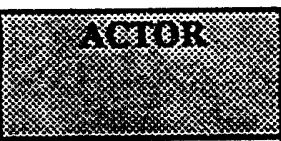 & 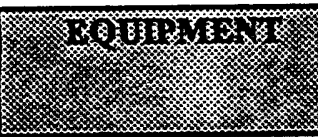 & (1) & 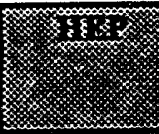 & 15is & $\frac{1}{x_{1}}$ \\
\hline $\mathbf{D}, \mathbf{E}$ & 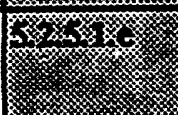 & $\begin{array}{l}\text { WM maintenance } \\
\text { \# } 1 \text { \& } 2\end{array}$ & $\begin{array}{l}\text { Flexible duct line \& } \\
\text { duct tape }\end{array}$ & Attach flexible duct line & & & \\
\hline$\overline{D, E}$ & 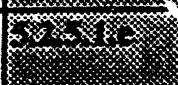 & WM maintenance & Blank flange & Remove blank flange & & & \\
\hline$\overline{D, E}$ & & $\begin{array}{l}\text { WM maintenance } \\
\text { \# } 1 \text { \& } 2\end{array}$ & Flexible duct line & $\begin{array}{l}\text { Attach flexible duct line to riser } \\
\text { down comer }\end{array}$ & & & \\
\hline & (x) & WM tank operator & & $\begin{array}{l}\text { Initiate SW16.1-SOP-WTE(48)- } \\
\text { 1, Attachment 28, Subsection } \\
\text { 8.28.1 }\end{array}$ & & & \\
\hline & & $\begin{array}{l}\text { WM tank operator } \\
\text { \#2 }\end{array}$ & $\begin{array}{l}\text { Emergency air purge } \\
\text { valves, portable fan } \\
\text { valves }\end{array}$ & $\begin{array}{l}\text { Independent Verification of } \\
\text { valve alignments }\end{array}$ & 0.05 & 5 & $20-22,3$ \\
\hline & & WM tank operator & Valve TK 48 HV-23 & $\begin{array}{l}\text { Open tank } 48 \text { Riser Emerg. Air } \\
\text { Purge Inlet Bypass Valve }\end{array}$ & 0.003 & 3 & $20-7,2$ \\
\hline & 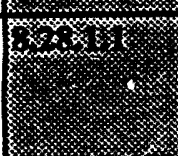 & WM tank operator & Valve TK 48 HV-24 & $\begin{array}{l}\text { Open tank } 48 \text { Riser Emerg. Air } \\
\text { Purge Inlet PDI-2027 Isolation } \\
\text { Valve }\end{array}$ & & & \\
\hline & (j) & WM tank operator & Valve TK 48 HV-25 & $\begin{array}{l}\text { Open tank } 48 \text { Riser Emerg. Air } \\
\text { Purge Inlet Bypass Valve }\end{array}$ & & & \\
\hline & (3. & WM tank operator & & $\begin{array}{l}\text { Inform 241-82H control room } \\
\text { operator procedure steps } \\
\text { completed }\end{array}$ & & & \\
\hline
\end{tabular}




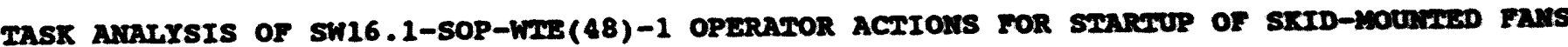

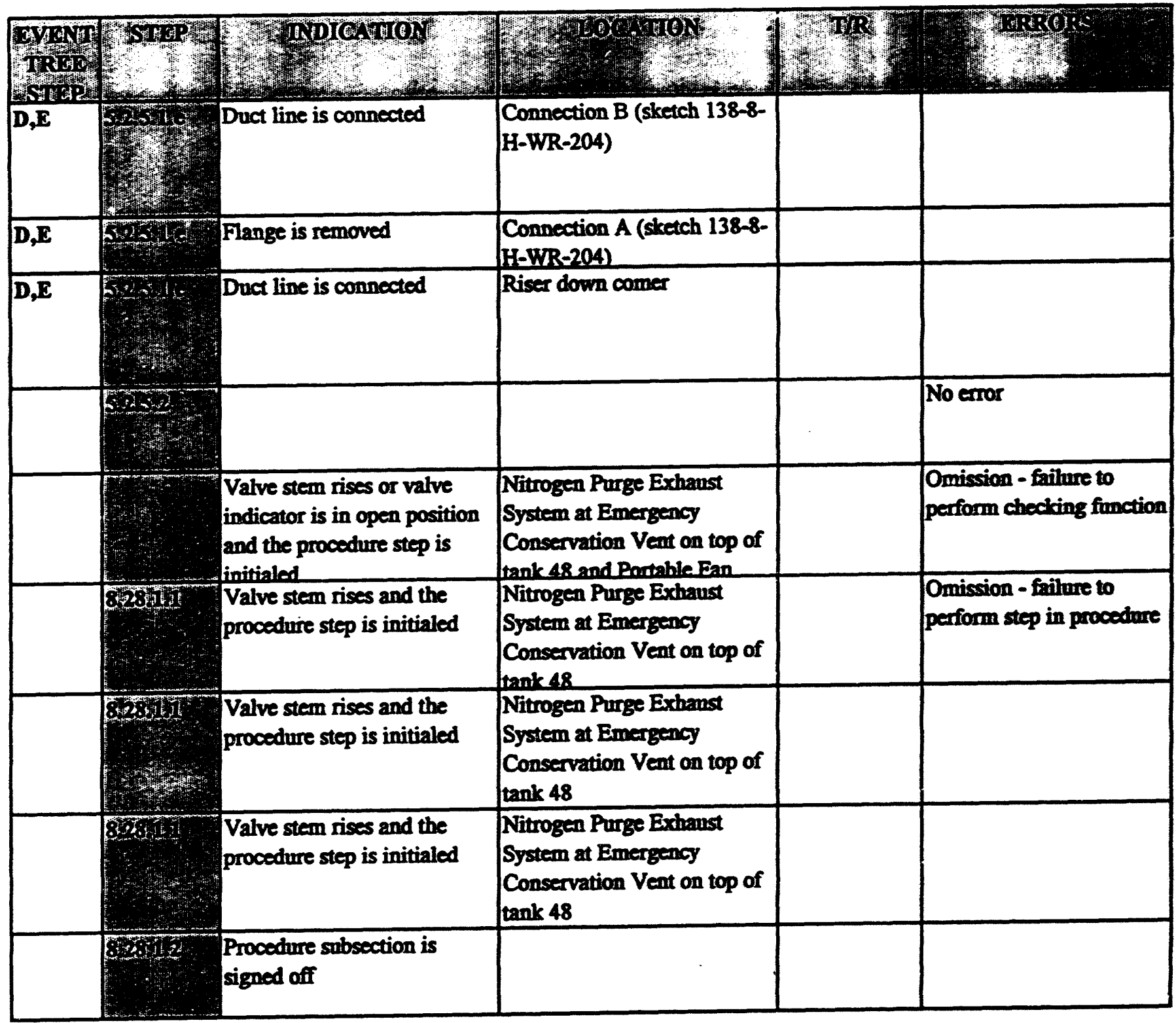


TAST AMAYYSIS OF SW16.1-SOP-WHE(48)-1 OPERATOR ACTIOAS FOR STARIUP OF SKID-MOUTHED FAMS

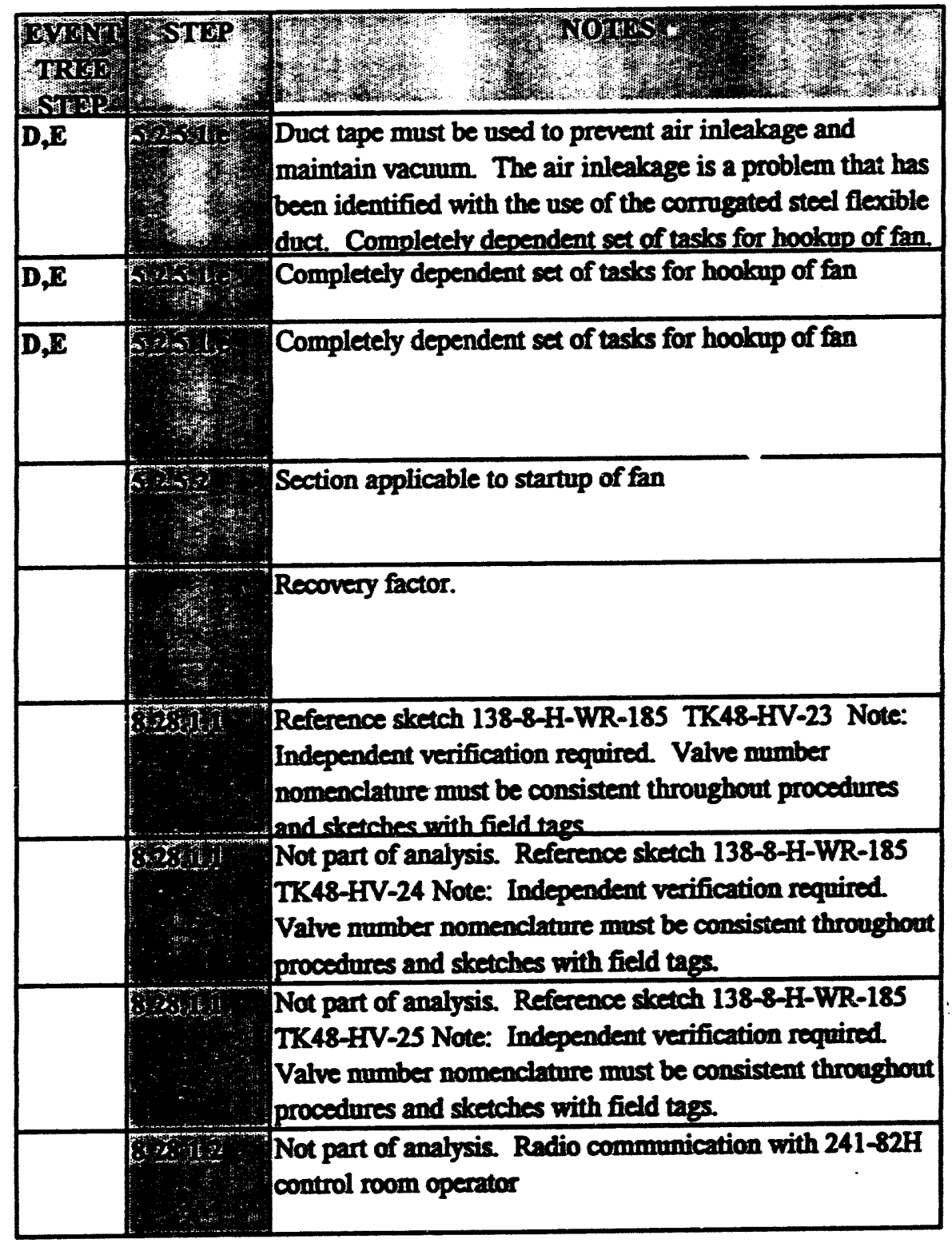




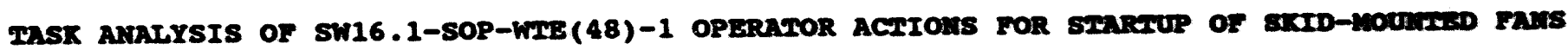

\begin{tabular}{|c|c|c|c|c|c|c|c|}
\hline 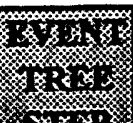 & 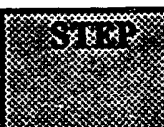 & . & (3) & 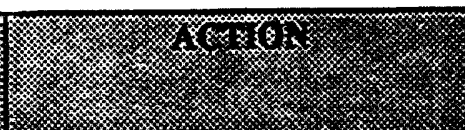 & int & 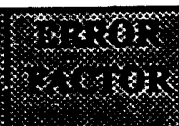 & mis \\
\hline $8 \sin$ & & WM tank operator & $\begin{array}{l}\text { Panel MCC SFA } \\
\text { Emergency exhaust } \\
\text { system } 480 \mathrm{~V} \\
\text { receptacles Tanks } 48\end{array}$ & Close circuit breaker 4J & & & \\
\hline & s. & WM tank operator & Valve HVPS \#2 & $\begin{array}{l}\text { Verify open Tank } 48 \text { Primary } \\
\text { Purge Emergency Filter Outlea } \\
\text { Isolation valve }\end{array}$ & 0.003 & 3 & $20-7,2$ \\
\hline & & WM tank operator & Valve HVPS $\# 3$ & $\begin{array}{l}\text { Verify open Tank } 48 \text { Primary } \\
\text { Purge Emergency Exhaust Fan } \\
\text { Valve }\end{array}$ & & & \\
\hline & & WM tank operator & Valve HVPS & $\begin{array}{l}\text { Open Tank } 48 \text { Primary Purge } \\
\text { Emergency Filter Inlet Isolation } \\
\text { Valve to approximately } 10 \% \\
\text { open }\end{array}$ & & & \\
\hline & & WM tank operator & Green start button & $\begin{array}{l}\text { Start Tank } 48 \text { Primary Purge } \\
\text { Emergency Exchanst Fan }\end{array}$ & & & \\
\hline & 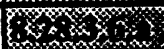 & WM tank operator & Analog gange & Adjust purge flow & & & \\
\hline & o. & WM tank operator & Analog gauge & Stop purge flow adjustments & & & \\
\hline & w & WM tank operator & Analog gange & $\begin{array}{l}\text { Notify WM operations } \\
\text { supervisor for instructions }\end{array}$ & & & \\
\hline
\end{tabular}




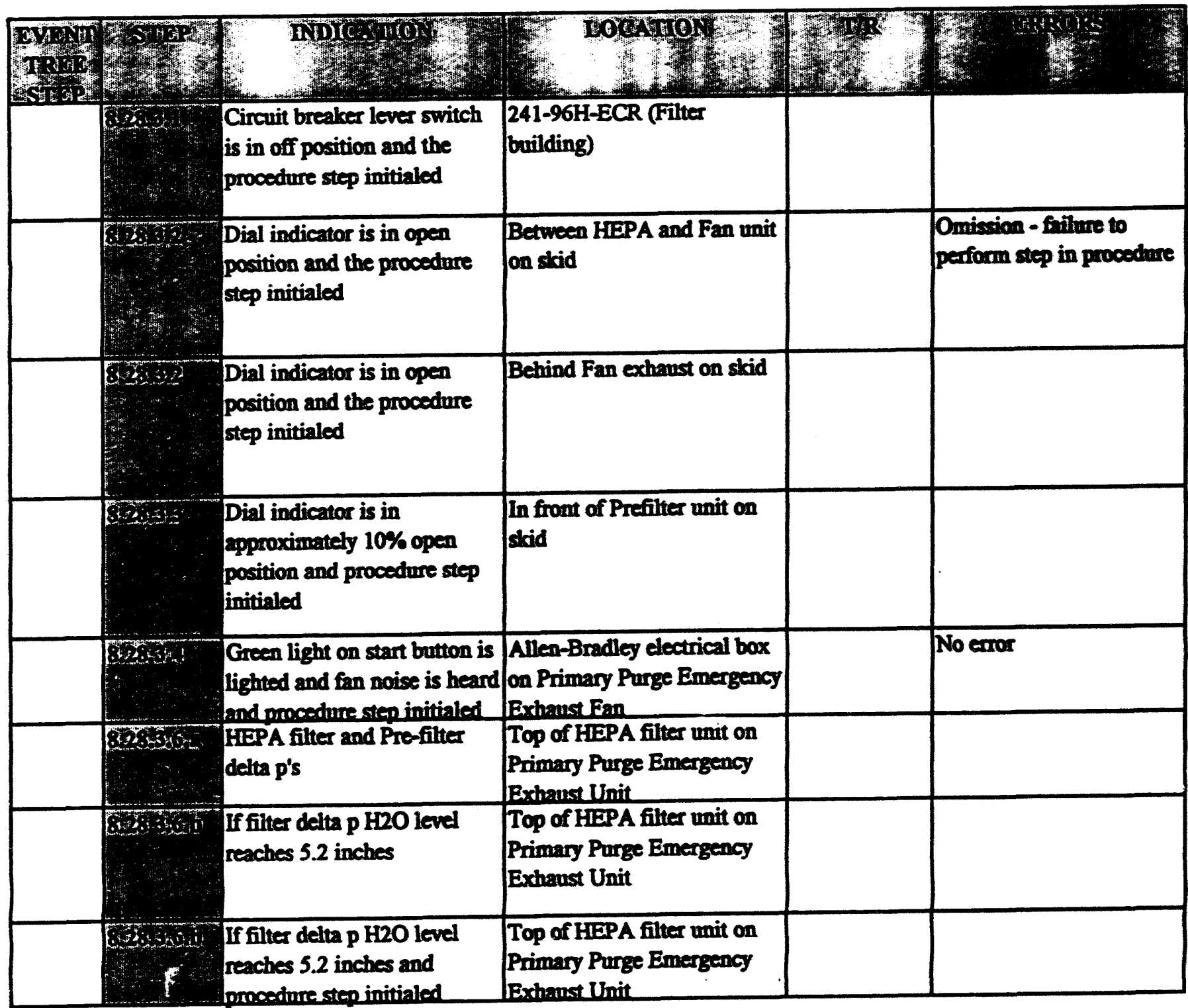


TASx AMAYSIS OF SW16.1-SOP-WIE(48)-1 OPERATOR ACTIOAS FOR STARUUR OF SKID-MOUNHED FAMS

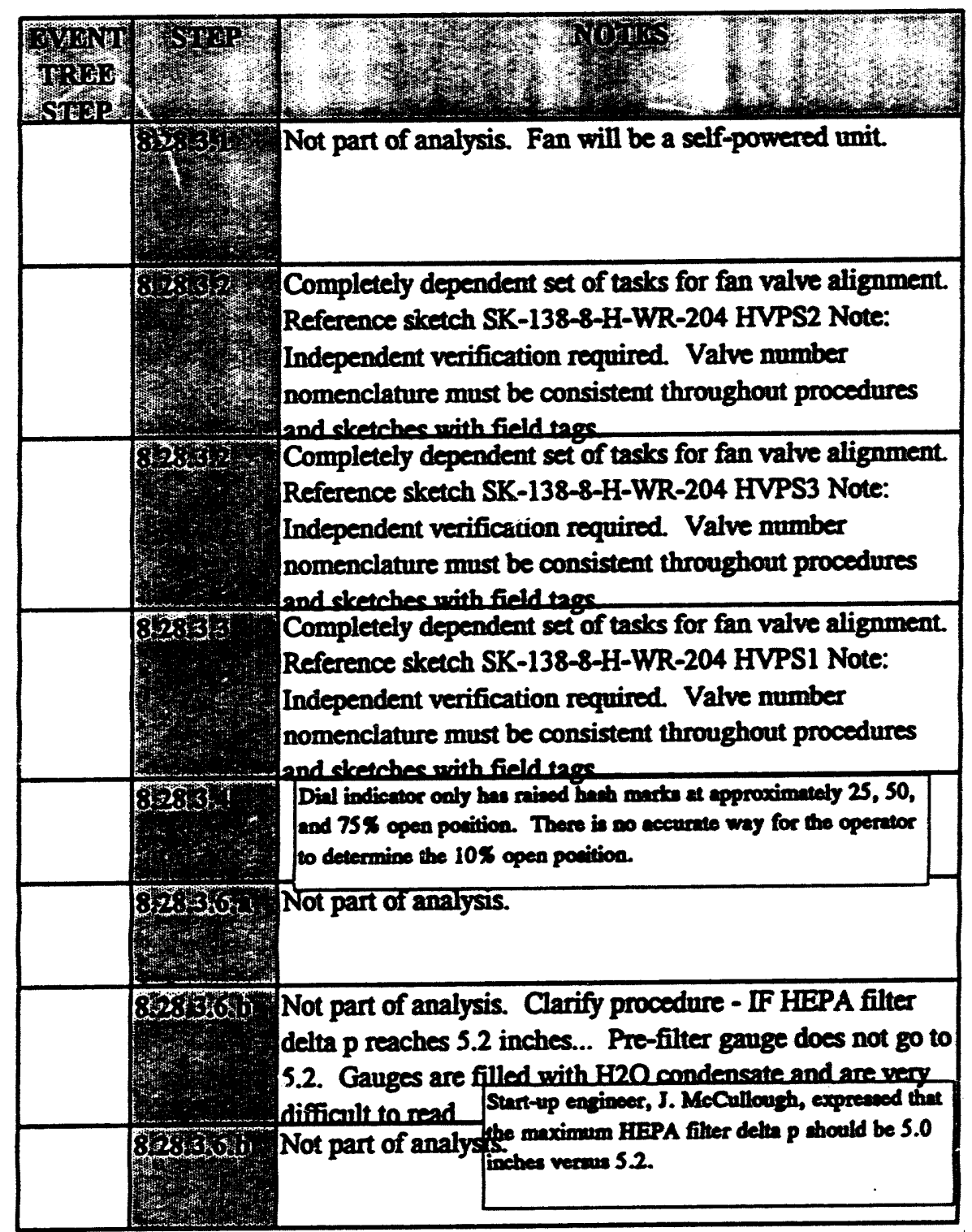


TASK AMAIYSIS OF SW16.1-SOP-WTE(48)-1 OPERATOR ACTIONS FOR STARTUP OF STID-MOUIIED FAMS

\begin{tabular}{|c|c|c|c|c|c|c|c|}
\hline PVENA & SPIMP & ACTOR & 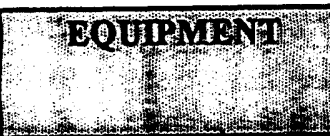 & W & Why & Weins & (5) \\
\hline & (3) & WM tank operator & Valve TK 48 HV-23 & $\begin{array}{l}\text { Throttle open Tank } 48 \text { Riser N } \\
\text { Emergency Air Purge Inlet } \\
\text { Bypass Valve }\end{array}$ & & & \\
\hline & & $\begin{array}{l}\text { WM tank operator } \\
\# 2\end{array}$ & Valve HVSP \#1 & $\begin{array}{l}\text { Throttle open Tank } 48 \text { Primary } \\
\text { Purge Emergency Filter Inlet } \\
\text { Isolation Valve }\end{array}$ & & & \\
\hline$\overline{\mathbf{H}}$ & & WM tank operator & Purge flow meter & Determine air flow & 0.15 & & $20-21,3 a$ \\
\hline $\mathbf{I}$ & & $\begin{array}{l}\text { WM maintenance } \\
\text { \# } 1 \text { \& } 2 \text { \& tank } \\
\text { operator }\end{array}$ & $\begin{array}{l}\text { All portable fan } \\
\text { connections \& valve } \\
\text { alignments }\end{array}$ & Diagnosis & 0.00001 & & $20-3,6$ \\
\hline $\mathbf{J}$ & & Health Physics or & Portable LEL analyzer & Measure \% LEL & 0.05 & & $20-21,2 a$ \\
\hline & Af & \multirow{4}{*}{\multicolumn{4}{|c|}{$\begin{array}{l}\text { NOTE: The remainder of Attachment } 28 \text { requires the tank operator to record a set of } \\
\text { readings initially and every } 2 \text { hours while the emergency purge unit is in operation. } \\
\text { There are approximately } 7 \text { gauges to be read and a calculation to be done as a part of } \\
\text { this procedure. However, for the purpose of the Safety Analysis Report, these } \\
\text { parameters are not critical and are not included in the probability calculations for } \\
\text { determining the likelihood of exceeding the Lower Flammability Limit. }\end{array}$}} & & \\
\hline & & & & & & & \\
\hline & & & & & & & \\
\hline & 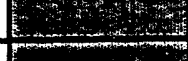 & & & & & & \\
\hline
\end{tabular}


TASK ANAIYSIS OF SW16.1-SOP-WTE(48)-1 OPERATOR ACTIONS FOR STARTUP OF SKID-MOUIIED FAYS

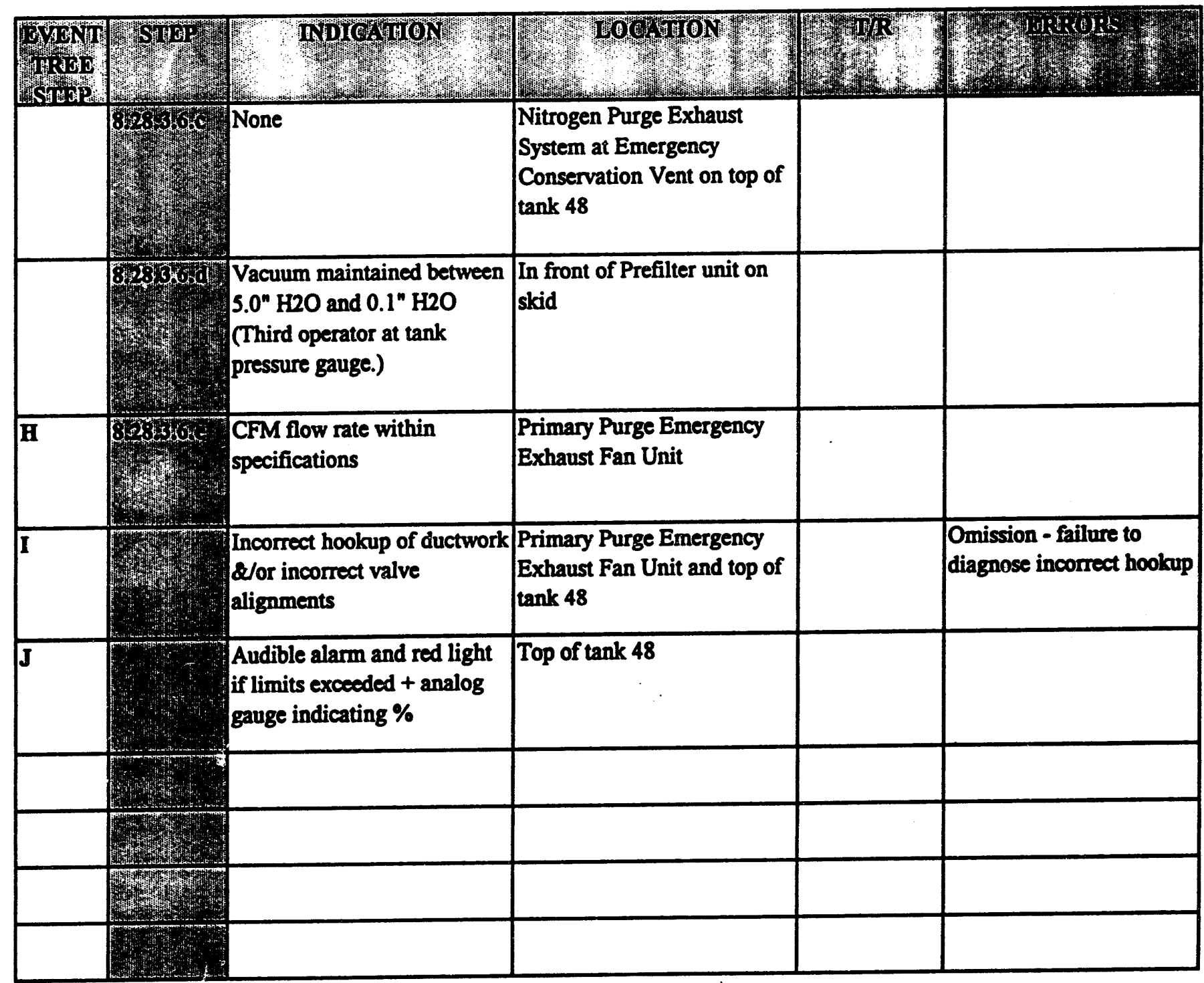


TASK ANALYSIS OF SW16.1-SOP-WTE(48)-1 OPERATOR ACTIONS FOR STARTUP OF SKID-MOUNIED FANS

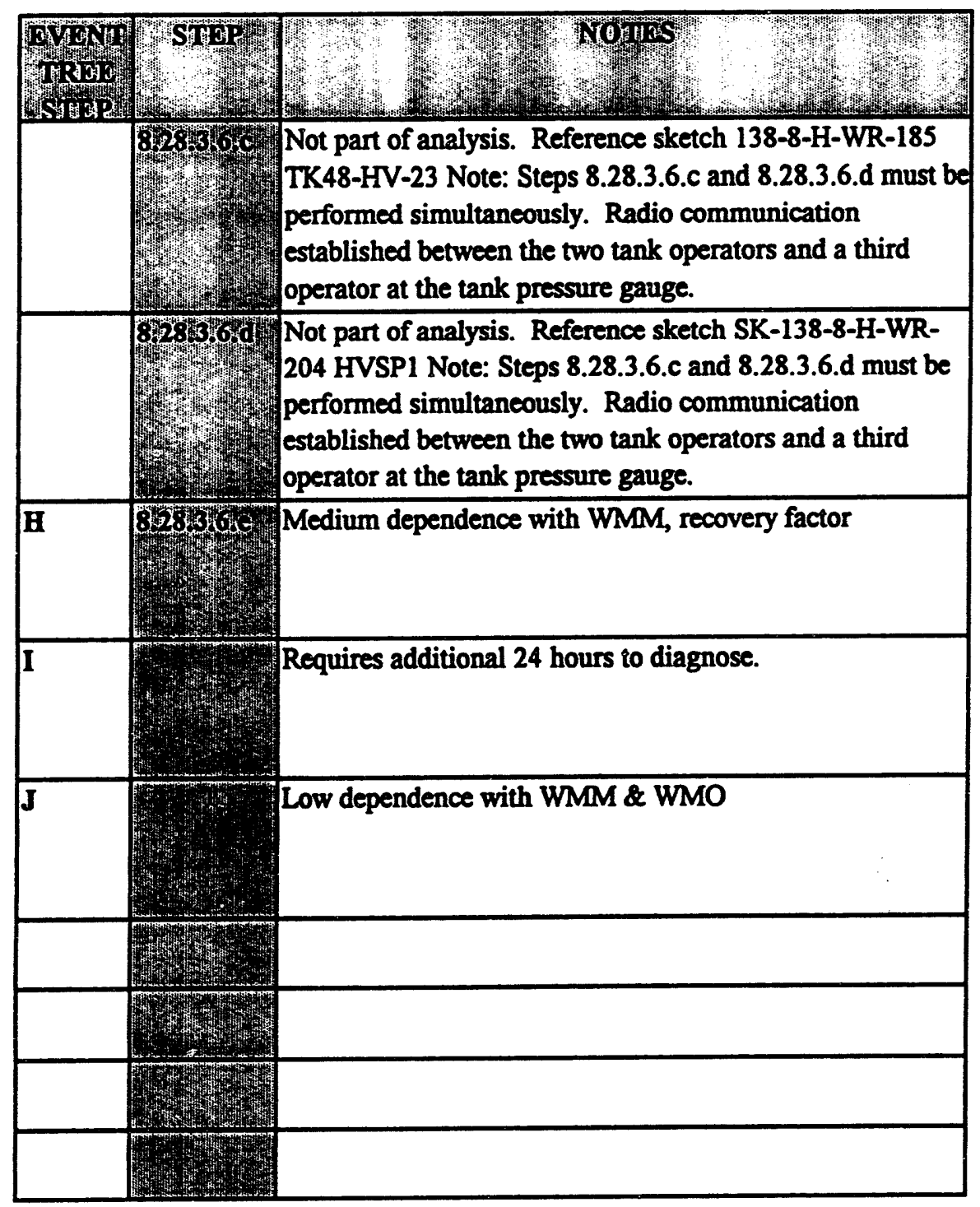




\section{APPENDIX C: TIMELINE}

3 DAYS

\begin{tabular}{c|c|c} 
DIAGNOSIS & $\begin{array}{c}\text { MOVE \& } \\
\text { INSTALL }\end{array}$ & EQUIPMENT OPERATING \\
\hline 10 hours & 7 hours & $\begin{array}{l}55 \text { hours } \\
\text { recovery }\end{array}$ \\
\hline
\end{tabular}

OSR Requirement to have purge equipt. on tank top

14 hours 


\section{WESTINGHOUSE SAVANNAH RIVER COMPANY \\ INTER-OFFICE MEMORANDUM}

NRTSC

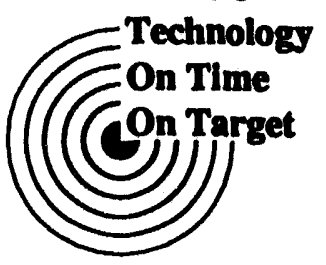

July, 16, 1993

TEMPORARY DELEGATION OF AUTHORITY

Delegating Manager:

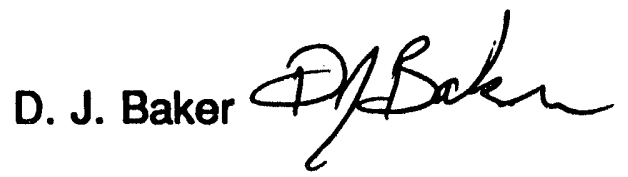

Department:

Safety Technology and Regulatory Analysis

Title:

Manager

I hereby delegate my signature authority to Jeff Lietzow and Carl Sossman during the period of $7 / 19 / 93-7 / 30 / 93$ for the purpose of vacation.

$/ \mathrm{cjt}$

CC: H. C. Benhardt, 992W-1

F. Beranek, 773-A

J. L. Fishpaw, 992W-1

P. C. Gaillard, 992W-1

M. J. Hitchler, 992W-1

J. S. Lietzow, 992W-1

K. R. O'Kula, 992W-1

C. L. Sossman, $992 W-1$

L. A. Wooten, 992W-1

ST\&RA Files 
11
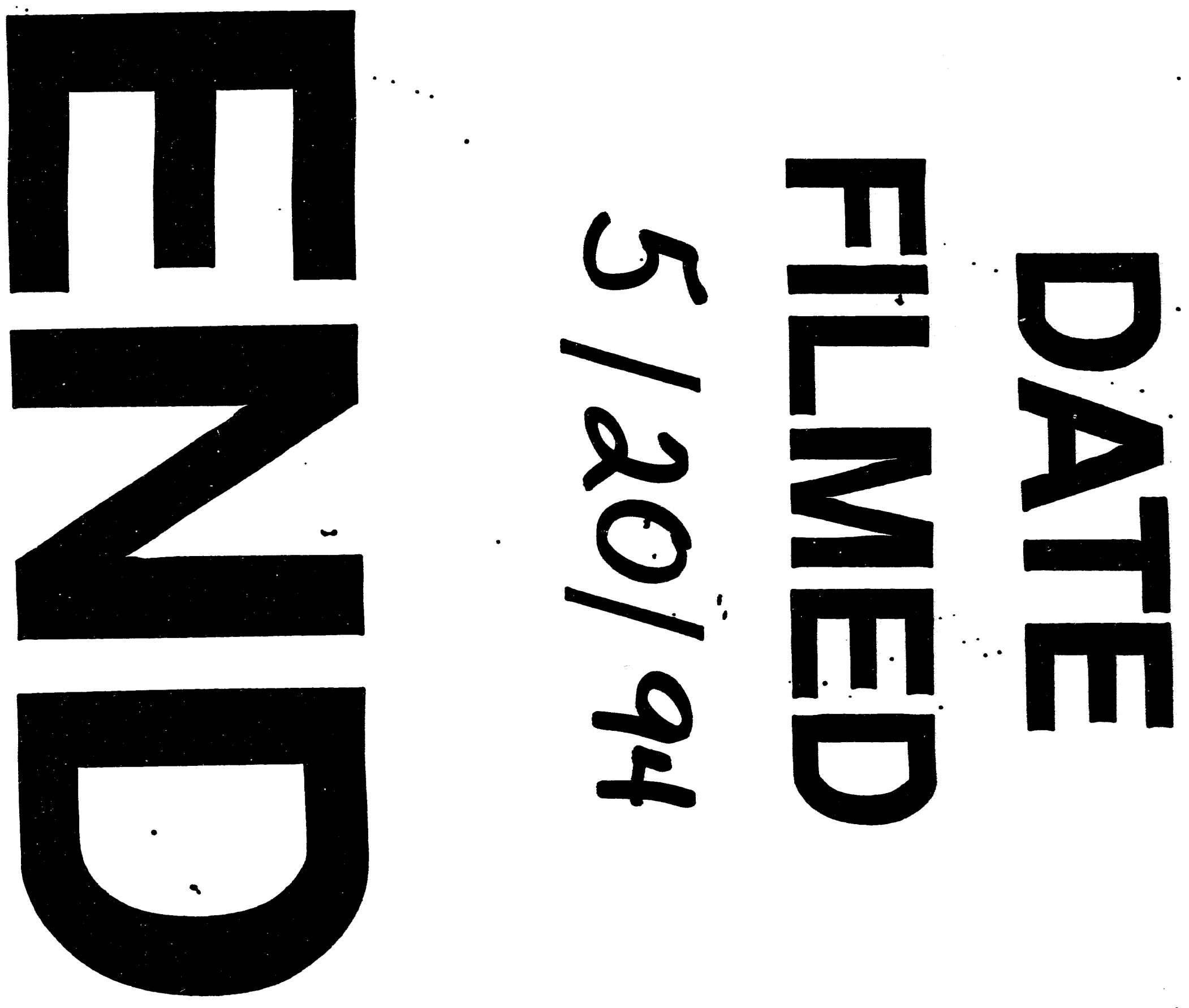

잉 

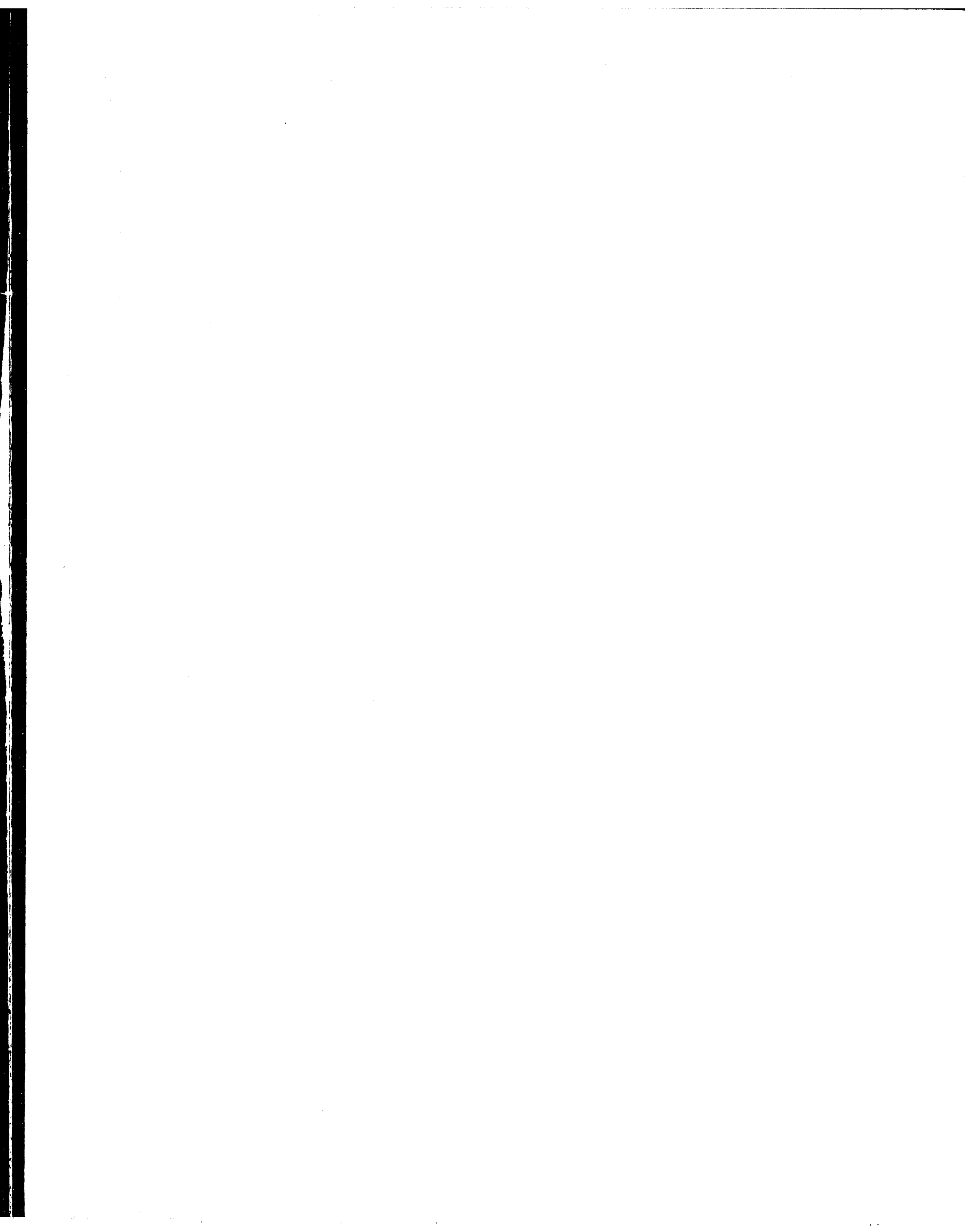